\title{
Long-term culture of undifferentiated spermatogonia isolated from immature and adult bovine testes
}

\section{$\operatorname{AUTHOR}(\mathrm{S}):$}

Suyatno; Kitamura, Yuka; Ikeda, Shuntaro; Minami, Naojiro; Yamada, Masayasu; Imai, Hiroshi

\section{CITATION:}

Suyatno ...[et al]. Long-term culture of undifferentiated spermatogonia isolated from immature and adult bovine testes. Molecular Reproduction and Development 2018, 85(3): 236-249

\section{ISSUE DATE:}

2018-03

URL:

http://hdl.handle.net/2433/230134

\section{RIGHT:}

This is the accepted version of the following article: [Suyatno, Kitamura Y, Ikeda S, Minami N, Yamada M, Imai H. Longterm culture of undifferentiated spermatogonia isolated from immature and adult bovine testes. Mol Reprod Dev. 2018;85:236-249], which has been published in final form at https://doi.org/10.1002/mrd.22958. This article may be used for non-commercial purposes in accordance with Wiley Terms and Conditions for Self-Archiving.; The full-text file will be made open to the public on 13 MAR 2019 in accordance with publisher's 'Terms and Conditions for Self-

Archiving'.; This is not the published version. Please cite only the published version.; この論文は出版社版でありません 。引用の際には出版社版をご確認ご利用ください。 
6 1'Laboratory of Reproductive Biology, Graduate School of Agriculture, Kyoto University,

7 Kyoto 606-8502, Japan

8 2Indonesian Agency for Agricultural Research and Development, J1. Ragunan 29, Pasar

9 Minggu, Jakarta Selatan 12540, Indonesia

$10{ }^{3}$ Laboratory of Animal Physiology and Functional Anatomy, Graduate School of Agriculture,

11 Kyoto University, Kyoto, 606-8502, Japan

12

$13 *$ Correspondence and reprint requests: Dr. Hiroshi Imai, Laboratory of Reproductive Biology,

14 Graduate School of Agriculture, Kyoto University, Kyoto 606-8502, Japan. Tel.: 81-75-7536058. Fax: 81-75-753-6329. E-mail: imai@kais.kyoto-u.ac.jp

16

17 This work was supported by a grant from the Ministry of Education, Science and Culture to HI 18 (grant 26292168).

19 $\alpha-1$; GSK3, glycogen synthase kinase-3 $\alpha$; KLF4, kruppel-like factor 4; MAPK, mitogen-

\section{Long-term culture of undifferentiated spermatogonia} isolated from immature and adult bovine testes 
25 determining region Y)-box 2; SSCs, spermatogonial stem cells; UCHL-1, ubiquitin carboxyl-

26 terminal hydrolase isozyme $\mathrm{L} 1$.

27

28 Abstract

Undifferentiated spermatogonia eventually differentiate in the testis to produce

30 haploid sperm. Within this cell population, there is a small number of spermatogonial

31 stem cells (SSCs). SSCs are rare cells in the testis, and their cellular characteristics are

32 poorly understood. Establishment undifferentiated cell line would provide an

33 indispensable tool for studying their biological nature and spermiogenesis/spermatogenesis

34 in vitro. However, there have been few reports on the long-term culture of undifferentiated spermatogonia in species other than rodents. Here, we report the

36 derivation and long-term in vitro culture of undifferentiated spermatogonia cell lines

37 from immature and adult bovine testes. Cell lines from immature testes were maintained in serum-free culture conditions in the presence of glial-cell-line-derived neurotropic factor

39 (GDNF) and bovine leukemia inhibitory factor (bLIF). These cell lines have embryonic stem

40 (ES)-like cell morphology, express pluripotent-stem-cell-specific and germ-cell-specific

41 markers at the protein and mRNA levels, and contributed to the inner cell mass (ICM) of

42 embryos in the blastocyst stage. Meanwhile, cell lines established from adult testes were

43 maintained in low-serum media in the presence of 6-bromoindirubin-3'-oxime (BIO). These

44 cell lines have characteristics resembling those of previously reported male mouse germ cell

45 lines as confirmed by their botryoidally aggregated morphology, as well as the expression of

46 germ-cell-specific markers and pluripotent stem cell markers. These findings could be useful

47 for the development of long-term culture of undifferentiated spermatogonia, which could 
aid in conservation of species and improvement of livestock production through genome

49 editing technology.

50 Keywords: adult male germ cells, cattle, spermatogonial stem cells, pluripotent stem cells.

\section{Introduction}

Spermatogenesis is achieved by a complex process, in which diploid SSCs proceed over time through a series of differentiation steps to produce haploid spermatozoa (de Rooij, 2001).

Since SSCs are rare cells in immature and adult testes (Tegelenbosch \& de Rooij, 1993), it is hard to isolate and study them and to distinguish them from their undifferentiated progeny.

Currently, several markers are used to identify SSCs in mice: GDNF family receptor $\alpha-1$

(GFR $\alpha-1)$ (Naughton et al., 2006), Thy-1 membrane glycoprotein (Thy-1) (Kubota, Avarbock,

\& Brinster, 2003) and inhibitor of DNA binding 4 (Id4) (Sun, Xu, Zhao, \& Chen, 2015).

In domestic species, gonocytes, SSCs, and SSC progenitors are identified by expressions of Dolichos biflorus agglutinin (DBA) (Fujihara, Kim, Minami, Yamada, \& Imai, 2011; Goel et al., 2007; Goel et al., 2010; Izadyar, Spierenberg, Creemers, den Ouden, \& de Rooiji, 2002), ubiquitin carboxyl-terminal hydrolase isozyme L1 (UCHL-1) (Fujihara, Kim, Minami,

64 Yamada, \& Imai, 2011; Goel et al., 2010; Heidari et al., 2012; Herrid, et al., 2007; Reding et al., 2010), and GFR $\alpha-1$ ( Costa et al., 2012; Lee et al., 2013; Oatley, de Avila, Reeve, \& McLean, 2004; ). However, the expression of biomolecular markers in germ cells from

67 domestic species is heterogeneous. They expressed in most of undifferentiated germ cells in 68 the testis (Zheng et al., 2014). This makes difficult to characterize SSCs from domestic animals.

69 Another method used to recognize SSCs is to identify their localization in the testis; SSCs are 70 located close to the basal membrane in the seminiferous tubules. 
It has been shown that in vitro culture of neonatal mouse SSCs allows to male germline stem (GS) cells (Kanatsu-Shinohara et al., 2003) and ES-like cells (Kanatsu-Shinohara et al., 2004) to be produced. Moreover, in vitro culture of adult mouse SSCs generates GS cells and multipotent male germline stem (MGS) cells (Guan et al., 2006; Seandel et al., 2007). GS cells form botryoidally aggregated colonies, retain their germ cell characteristics, and contribute to the germ cell lineage (Kanatsu-Shinohara et al., 2003). By contrast, ES-like cells form tightly packed 3-dimensional colonies, express pluripotent stem cell markers, and contribute to chimeras (Kanatsu-Shinohara et al., 2004; Ko et al., 2009). MGS cells have tightly packed 3dimensional colonies, express pluripotent stem cell markers, and develop into cardiac tissue in vitro and functional blood vessels in vivo (Seandel et al., 2007). Moreover, genetically modified cultured SSCs produced transgenic animals (Kanatsu-Shinohara et al., 2008). This suggests that cultured SSCs can be a useful tool for making genetic modifications through gene targeting and genome editing technologies.

Undifferentiated spermatogonia including SSCs from neonatal and pre-pubertal stage of domesticated animal such as pig (Zheng et al., 2013; Zhang et al., 2017) and goat (Pramod and Mitra, 2014) can also be cultured in vitro. In cattle, although gonocytes and SSCs isolated from neonatal and immature bovine testes can be maintained in culture (Aponte, Soda, van de Kant, \& de Rooij, 2006; Fujihara, Kim, Minami, Yamada, \& Imai, 2011; Izadyar et al., 2002; Oatley, Kaucher, Yang, Waqas, \& Oatley, 2016; Sahare et al., 2016), long-term culture systems for SSCs from adult testes have been established only in mice.

Several growth factors including GDNF are employed to derive germ cell lines from immature bovine testes (Oatley, Kaucher, Yang, Waqas, \& Oatley, 2016; Sahare et al., 2015) .

93 GDNF is produced by Sertoli cells and supports mouse SSC proliferation in vivo (Meng et al., 94 2000) and in vitro (Hasegawa, Namekawa, \& Saga, 2013). In cattle, the addition of GDNF to 
culture medium activates the mitogen-activated protein kinase (MAPK) signaling pathway and supports long-term proliferation of gonocyte isolated from neonatal and immature testes (Sahare et al., 2015). However, when the neonatal culture system was applied to culture adult bovine spermatogonia, they could not be maintained for a long time (Fujihara, Kim, Minami, Yamada \& Imai, 2011 ). Hence, experimental evidence suggests that the establishment of male germ cell lines seems to be dependent on the age of the animal from which the cells are derived. The application of male germ cell lines in domestic species will be more comprehensive when it have been established from both immature and adult animals.

In this study, we developed different culture systems for bovine undifferentiated spermatogonia isolated from both immature and adult testes and characterized the cells. This finding demonstrates the feasibility of male germ cell culture in domestic species, which could facilitate progress in research related to transgenic animal production, genome editing technology for improvement of livestock production or conservation of endangered species.

\section{Results}

\subsection{Differential gene expression in undifferentiated spermatogonia of immature and} adult testes

The expression patterns of undifferentiated spermatogonia markers from immature and adult testes was compared. Differential expression patterns of both GFR $\alpha$-1-positive and UCHL-1-positive cells were observed (Figure 1a-1e). The number of UCHL-1positive cells was higher in immature testes $(57.11 \pm 7.93 \%)$ than in adult testes $(34.25 \pm$ $3.80 \%)(\mathrm{n}=6$, Figure 1c). A similar result was observed for another undifferentiated spermatogonia marker, GFR $\alpha-1$, in immature testes $(37.61 \pm 4.94 \%)$ and in adult testes (7.14 $\pm 3.1 \%$ ) (Figure 1d). These results were also confirmed by RT-PCR (Figure 1e). 


\subsection{Enrichment for undifferentiated spermatogonia isolated from adult testes}

In adult testicular cell suspensions, two fractions that appeared at approximately

$12220 \%$ and $40 \%$ Percoll gradients were collected after gradient centrifugation. Cell

123 suspensions were seeded in pregelatinized dishes for $2 \mathrm{~h}$ to allow somatic cells to attach

124 to the dishes, and the floating cell suspensions were collected. DBA-positive cells were

125 identified in both the $20 \%$ and $40 \%$ Percoll fractions. In the preliminary experiments, the

126 isolated fractions were evaluated for colony formation by short-term culture. Cells that

127 were collected from the $20 \%$ fraction formed colonies and could be passaged for further

128 expanded culture. In contrast, cells from the $40 \%$ fraction did not form colonies and could

129 not proliferate after primary culture (Figure S1a-S 1b). Therefore, only the cell suspension

130 from the $20 \%$ fractions was used for further studies. The number of SSCs in culture was

131 estimated by UCHL-1 and DBA staining (Figure 2a-2b). The percentage of UCHL-1-

132 positive cells in the freshly isolated cell suspensions was $10.03 \pm 3.22 \%$ and significantly

133 increased to $27.71 \pm 10.46 \%$ after Percoll gradient centrifugation, then further increased

134 to $36.81 \pm 11.52 \%$ after negative selection on gelatin-coated dishes (Figure 2c-2d).

135 Similar results were obtained by using DBA staining (before Percoll: $15.31 \pm 2.87 \%$; after

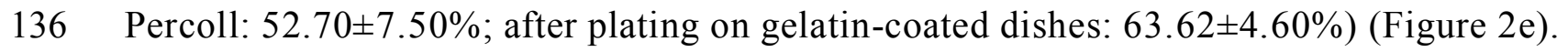

2.3 Derivation of cell lines from undifferentiated spermatogonia of immature bovine testes

Enriched populations of undifferentiated spermatogonia from immature bovine testes

141 were isolated from 3-month-old calves. Isolated cells were cultured in medium containing both

$14215 \%$ KSR and 1\% FBS and supplemented with GDNF for the initial culture. After 5 to 7 days 
143 in primary culture, the cultured cells formed botryoidally aggregated multicellular colonies.

144 After the first passage, the culture medium was changed to DMEM/F12 medium

145 supplemented with $20 \%$ KSR, and the cells were passaged every 5 days. In the later passages

146 (passages 7 and 8), the cultures were passaged every 2 to 3 days owing to robust proliferation

147 of undifferentiated spermatogonia. The cell lines formed botryoidally aggregated colonies in

148 primary culture (Figure 3a, white arrow) and gradually changed their morphology to become

149 dome-shaped ES cell-like colonies after several passages (Figure 3a, black arrow).

The effects of different growth factors on the proliferation of undifferentiated spermatogonia were also tested. We compared the effect of KSR media supplemented with GDNF only, bLIF only, and a combination of GDNF and bLIF on the number of colonies formed (Figure 3b) and the total number of cells (Figure 3c). The results suggested that there were no significant differences among different culture conditions (Figure 3b-3c). However, RT-PCR results revealed that the colonies cultured in the presence of bLIF or GDNF and bLIF strongly expressed $U C H L-1$ after long-term culture (Figure 3d).

2.4 Characterization of cell lines from undifferentiated spermatogonia of immature bovine testes

RT-PCR analysis was performed on freshly isolated undifferentiated spermatogonia and 4 cultured cell lines at passage 8 and passage 19 (Figure 4a). Freshly isolated undifferentiated spermatogonia express pluripotency-associated genes (NANOG, OCT4, SOX2,

163 and $K L F 4$ ), as well as the germ cell marker $U C H L-1$. Cell lines also expressed OCT4, SOX2 164 and KLF4 and $U C H L-1$ at passage 8. At the passage 19, however, only KLF4 and $U C H L-1$ were detected (Figure 4a). Immunofluorescent analysis was performed on the cell lines and detected a pluripotent marker (SOX2) and germ cell markers (UCHL-1 and DBA) (Figure 4b). 


\subsection{Derivation of cell lines from undifferentiated spermatogonia of adult bovine testes}

Isolated undifferentiated spermatogonia were cultured in one of four different

170 media: 1) the basic medium (DMEM/F12 containing 15\% KSR and 1\% FBS), 2) the

171 basic medium supplemented with GDNF only, 3) the basic medium supplemented with

172 BIO only, or 4) the basic medium supplemented with both GDNF and BIO. After 7 days

of primary culture, colonies were observed (Figure 5a). There were no differences in the

total number of cells in the primary cultures ( $\mathrm{P} 0)$ among the different culture conditions

175 (Figure 5b). RT-PCR analysis showed that P0 colonies expressed the germ cell marker

176 gene $U C H L-1$ (Figure 5c). In the basic medium or the basic medium with GDNF only,

177 however, enhanced proliferation of somatic cells was observed, and those cells overwhelmed the growth of germ cell colonies at the first passages (Figure 5a). On the other hand, the basic medium with BIO or the basic medium with BIO and GDNF

180 similarly allowed the grow of germ cell colonies (Figure 5a); therefore, only the basic medium with BIO was used as a culture medium for further experiments.

2.6 Characterization of cell lines from undifferentiated spermatogonia of adult bovine testes

Typical germ cell colonies were maintained in the presence of BIO (Figure 6a).

RT-PCR analysis performed on the colonies at passages 3,8 and 10 showed that the germ-cell-specific marker $U C H L-1$ was stably expressed, and the stem-cell specific markers $O C T 4$ and KLF4 were also detected with a slightly different expression pattern than SOX2 (Figure 6b). Moreover, immunofluorescence analysis confirmed the 
191 culture enriched cell suspensions from a 17-year-old bull. Colonies appeared in the

192 presence of BIO and were maintained for at least 3 passages (Figure S3a). The expression 193 of $U C H L-1$ was shown by RT-PCR at passage 2 (Figure S3b).

2.7 Karyotype analysis of cell lines from undifferentiated spermatogonia of immature and adult bovine testes

Karyotype analysis also showed normal metaphase spreads and chromosome number

$198(2 \mathrm{n}=60)$ in SSC cell lines from immature testes $(93,3 \%, 28$ out of 30 spreads $)$ and adult testes (96.7\%, 29 out of 30 spreads), while $6.67 \%$ had 59 chromosomes in cell lines from immature testes and 3.33\% had 59 chromosomes in cell lines from adult testes (Figure 7a-7b).

\subsection{Stem cell potential of established cell lines}

To examine the stem cell potential of cell lines from both immature and adult bovine

testes, we tagged the cells with a long-term fluorescent tracer and allowed them to aggregate into embryos in the 8- to 16-cell stages (Figure 7c). Cell lines from immature testes were incorporated into the ICM of blastocysts $(26.67 \%$, Table 1$)$, whereas cell lines from adult testes only scattered around embryos or formed cell clumps outside of embryos (Figure 7c), and a few of them incorporated specifically into the TE region of embryos (15.38, Table 1). In contrast, neither freshly isolated cells nor bovine embryonic fibroblasts (BEFs) were

210 incorporated into the embryos. Bovine naïve-type iPS cells, which were previously established

211 (Kawaguchi et al., 2015), were used as positive control. These cells were highly incorporated

212 into the embryos (14.29\% ICM only and $85.71 \%$ ICM and TE, Table 1$)$. 
215 Cell suspensions from immature and adult bovine testes were purified by Percoll gradient

216 centrifugation. The proportions of UCHL-1-positive and GFRa-1 positive cells in the cell

217 suspensions from immature testes were higher and sufficient to enrich undifferentiated

218 spermatogonia by Percoll gradient centrifugation (Figure 1c-1d). However, the population of

219 undifferentiated spermatogonia in adult testicular cell suspension was significantly lower than

220 that from immature testes (Figure 1c-1e). Differential plating on gelatin-coated dishes after

221 Percoll gradient centrifugation was necessary to enrich undifferentiated spermatogonia from

222 adult testes.

223 Undifferentiated spermatogonia from immature testes formed colonies in culture in the

224 presence of GDNF and FBS; however, testicular somatic cells also proliferated and overgrew

225 in the cultures after a few passages (Figure S4). By contrast, when undifferentiated

226 spermatogonia were cultured under serum-free conditions in the presence of KSR medium

227 containing both GDNF and bLIF, undifferentiated spermatogonia colonies were formed and

228 maintained for a long period.

229 The colonies derived from immature testes undifferentiated spermatogonia were identified

230 by their botryoidally aggregated cell morphology (Figure 3a) and then transformed to tightly

231 packed 3-dimensional colonies, similar to mouse ES cells, after a month of culture (Figure 3a).

232 These ES cell-like colonies were maintained for only 2 months (11 passages); however, the

233 botryoidally aggregated colonies were more stable and could be maintained for more than 3

234 months under serum-free culture conditions. SSCs isolated from neonatal mouse testes start to

235 form ES-like colonies within 4-7 weeks after initial culture (Kanatsu-Shinohara et al., 2004)

236 and can subsequently be cultured under ES cell culture conditions while maintaining their ES-

237 like properties (Kanatsu-Shinohara et al., 2004). ES-like bovine undifferentiated

238 spermatogonia colonies were cultured on STO feeder cells, which is the same culture condition 
used for previously established bovine naïve-type iPS cells (Kawaguchi et al., 2015); however,

240 they could not be maintained under this condition.

241 The established cell lines from immature testes had mouse ES cell-like morphology in

242 serum-free medium supplemented with GDNF and bLIF, and they expressed both germ-cell-

243 specific (UCHL-1 and $D B A$ ) and pluripotent stem cell markers (OCT4, SOX2, KLF4).

244 Consistent with our results, other studies have reported that in vitro culture of gonocytes from

245 neonatal bovine testes yields ES cell-like colonies (Sahare, Otomo, Komatsu, Minami, Yamada,

246 \& Imai, 2015) that express cell surface markers of ES cells (Li et al., 2016). In contrast, isolated

247 undifferentiated spermatogonia from adult testes could be maintained in the medium only in

248 the presence of BIO and formed colonies with botryoidally aggregated cell morphology,

249 similar to typical mouse GS cells. All 4 established cell lines expressed the germ-cell-specific

250 markers UCHL-1, DBA, and GFR $\alpha-1$ and the pluripotent stem cell markers OCT4, SOX2, and

$251 K L F 4$. BIO is an inhibitor of glycogen synthase kinase-3 $\alpha$ (GSK3) (Sato, Meijer, Skaltsounis,

252 Greengard, \& Brivanlou, 2004). Inhibition of GSK3 leads to the activation of the Wnt/ $\beta$ catenin signaling pathway. As recently reported in tree shrew (Li et al., 2017), Wnt/ $\beta$-catenin signaling pathway is involved in the maintenance of undifferentiated spermatogonia from adult testes during the early stage of in vitro culture. Moreover, Wnt signaling also supports regulation of the character as stem cells of mouse spermatogonial stem/progenitor cells

257 (Golestaneh, Beauchamp, Fallen, Kokkinaki, Üren, \& Dym, 2009) and promotes the proliferation of SSC progenitor cells (Takase \& Nusse, 2016).

In this study, undifferentiated spermatogonia isolated from immature testes could be maintained for long term in the basic medium with GDNF. Therefore, we hypothesized that once adult undifferentiated spermatogonia gained stem cell-like properties in the presence of

$262 \mathrm{BIO}, \mathrm{BIO}$ could be omitted from the culture and replaced by GDNF. After removal of BIO at 
264 Moreover, colonies could not be maintained in culture by the removal of BIO before 10

265 passages. This result suggests that during the first 10 passages in the presence of BIO, a

266 fraction of undifferentiated spermatogonia in heterogeneous differentiated states in the adult

267 testis may transform to more undifferentiated states such as SSCs. In contrast, undifferentiated spermatogonia from immature testes could be maintained in the presence or absence of BIO with no significant differences (data not shown).

To examine the stem cell potential of the established cell lines, we co-cultured three different cell lines with in vitro fertilized bovine embryos at 8 to 16 cell stage. Cell lines from immature testes were incorporated into the ICM region in $26.67 \%$ of blastocysts (Table 1 and

273 Figure 7C); however, none of the freshly isolated undifferentiated spermatogonia could be incorporated into blastocysts. In contrast, the contribution of cell lines from adult testes was limited, consistent with a study showing that the contribution of mouse SSC-derived cell lines to chimeras is dependent on the age of the testes (Azizi et al., 2016). In our previous reports (Kawaguchi et al., 2015), established naïve-type bovine iPS cells were abundantly incorporated into both the ICM and TE regions of blastocysts after aggregation with 8-cell and 16-cell embryos. Taken together, the evidence shows that cells of cell lines derived from immature testes have partial stem cell potential, probably because of a heterogeneous stem cell population in the established cell lines or a cell population with both stem cell and germ cell characteristics,

282 but those from adult testis have narrower limits on their potential as stem cells. However,

283 further studies are necessary to examine the ability of the cell lines to contribute to chimeric 284 fetuses and contribute to spermatogenesis through their germ cell potential in bovine testes. spermatogonia from a 17-year-old bull that was a sire but was no longer used for semen collection. Isolated undifferentiated spermatogonia from that bull could be successfully

288 cultured for 3 passages at most (Figure S3), and the population of undifferentiated 
spermatogonia in the testis was very limited (Figure S1). Procedures for enrichment of the undifferentiated spermatogonia population and stimulation of undifferentiated spermatogonia

291 proliferation are necessary for aged and seasonally breeding animals.

292

\section{Materials and Methods}

\subsection{Ethical statement}

All animal experiments were performed in accordance with the "Welfare Management of Livestock" standards of Gifu Prefectural Livestock Research Institute and the guidelines of the Kyoto University Livestock Farm and were approved by the Kyoto University Animal Care and Use Committee.

\subsection{Isolation of undifferentiated spermatogonia from bovine testes}

Undifferentiated spermatogonia were isolated by sequential enzymatic digestion methods as previously reported (Fujihara, Kim, Minami, Yamada, \& Imai, 2011) with minor modifications. Briefly, the testes were collected from Japanese Black cattle of the following ages: 3 months old, 1 to 2 years old, and 17 years old. The collected testes were placed immediately into a tube and immersed in Dulbecco's modified Eagle's medium (DMEM)/F12 medium (GIBCO BRL Invitrogen, Carlsbad, CA, USA) supplemented with 100

IU mL $\mathrm{mL}^{-1}$ penicillin (Sigma-Aldrich, St. Louis, MO, USA), $50 \mathrm{mg} \mathrm{mL}^{-1}$ streptomycin (Sigma-

308 Aldrich), $40 \mathrm{mg} \mathrm{mL}^{-1}$ gentamicin sulfate (Sigma-Aldrich) and $15 \mathrm{mM} \mathrm{HEPES} \mathrm{(Wako,} \mathrm{Osaka,}$ Japan). The testes were transported to the laboratory at $4^{\circ} \mathrm{C}$ to $10^{\circ} \mathrm{C}$ within $24 \mathrm{~h}$. To prepare cell suspensions, we minced the decapsulated testicular tissues and treated with a three-

311 step enzymatic digestion method. The cells were incubated with the first collagenase

312 solution for $50 \mathrm{~min}$ at $37^{\circ} \mathrm{C}$, then washed three times with $\mathrm{DMEM} / \mathrm{F} 12$. This was followed by

313 incubation with a second collagenase solution for $50 \mathrm{~min}$ at $37^{\circ} \mathrm{C}$, after which the cells were 
314 washed again three times with DMEM/F12. The obtained suspensions were centrifuged, and

315 the resulting cell pellets were incubated with a third collagenase solution for on $1 \mathrm{y} 10 \mathrm{~min}$

316 at $37^{\circ} \mathrm{C}$, washed three times and filtered through a $50-\mu$ m nylon mesh.

4.3 Enrichment of isolated undifferentiated spermatogonia from immature bovine testes

Percoll gradient centrifugation was used for enrichment of undifferentiated spermatogonia isolated from immature testes. We used a Percoll gradient of $60 \%, 40 \%$, and 20\% Percoll (GE Healthcare Life Sciences, Sweden) as previously reported (Fujihara, Kim, Minami, Yamada, \& Imai, 2011) with minor modifications. Cell suspensions were loaded on top of the Percoll gradients and centrifuged at 3,000 rpm for $30 \mathrm{~min}$. After centrifugation, different cell fractions were observed. The germ-cell fraction was collected from the $20 \sim 40 \%$ Percoll fraction. The purity of the fraction was assessed by immunofluorescence staining of cell suspensions for GFR $\alpha-1$ and UCHL-1.

\subsection{Enrichment of isolated undifferentiated spermatogonia from adult bovine testes}

Since undifferentiated spermatogonia are a rare cell population in the adult testis, the undifferentiated spermatogonia fraction of the filtered suspension of adult testicular cells was enriched by a two-step purification protocols. Percoll gradient centrifugation was performed as the first germ cell selection step, and the germ cells were collected from the $20 \sim 40 \%$ Percoll fraction. Subsequently, differential plating of the cell suspension on a gelatin-coated culture dish were used to remove any additional remaining somatic cells from the enriched Percoll fractions. The undifferentiated spermatogonia-rich fractions were plated on $0.1 \%$ pregelatinized dishes in DMEM/F12 media supplemented with 5\% fetal bovine serum (FBS,

337 Invitrogen) for $2 \mathrm{~h}$. Most of the somatic cells attached to the culture dish, while the 
studies. The purity of the cell suspensions was assessed by immunofluorescence staining for DBA and UCHL-1.

\subsection{Histological analysis of the testes}

Isolated testes were fixed with Bouin's solution, embedded in paraffin using standard

344 procedures, and sliced to a thickness of $6 \mu \mathrm{m}$. The paraffin sections were deparaffinized, rehydrated, and stained with hematoxylin and eosin.

\subsection{Culture of undifferentiated spermatogonia isolated from immature bovine testes}

L-lysine $(0.01 \%)$-precoated wells in 24 -well plates with basic media containing DMEM/F12, $100 \mu \mathrm{g} / \mathrm{mL}$ penicillin (Sigma-Aldrich), $50 \mu \mathrm{g} / \mathrm{mL}$ streptomycin (Sigma-Aldrich), $40 \mu \mathrm{g} / \mathrm{mL}$ gentamycin sulfate (Sigma-Aldrich), $10 \mu \mathrm{g} / \mathrm{mL}$ apotransferrin (Sigma-Aldrich), $10 \mu \mathrm{g} / \mathrm{mL}$ insulin (Sigma-Aldrich), $110 \mu \mathrm{g} / \mathrm{mL}$ sodium pyruvate (Sigma-Aldrich), 0.015\% (v/v) sodium lactate (Sigma-Aldrich), $0.1 \%$ (v/v) non-essential amino acid solution (GIBCO BRL Invitrogen), and $0.01 \mathrm{mM} \beta$-mercaptoethanol (Wako). In the initial culture, the basic media were supplemented with $15 \%$ knockout serum replacement (KSR), 1\% FBS and $20 \mathrm{ng} / \mathrm{ml}$ GDNF. After the first passage, the media were replaced with DMEM/F12 supplemented with $20 \%$ KSR and growth factors. Different growth factors-GDNF, bLIF, or both in conjunction-were added to find the optimal culture conditions for undifferentiated

360 GDNF and bLIF. The culture media were changed every 3 days. 
364 at a cell density of $5 \times 10^{4}$ cells $/ \mathrm{cm}^{2}$ on poly-L-lysine $(0.01 \%)$-precoated 24 -well plates (Nunc)

365 using DMEM/F12 supplemented with 15\% KSR (Invitrogen) and 1\% FBS. Culture conditions

366 for undifferentiated spermatogonia were studied using four different culture media: the basic

367 medium only, the basic medium supplemented with $20 \mathrm{ng} / \mathrm{ml}$ GDNF (Peprotech), the basic

368 medium supplemented with $2 \mu \mathrm{M}$ of $\mathrm{BIO}$, and the basic medium supplemented with both

369 GDNF and BIO. After 6 to 7 days of primary culture, multicellular botryoidally aggregated

370 colonies were observed in all cultures. The cells were passaged with $0.25 \%$ trypsin and 0.5

$371 \mathrm{mM}$ EDTA (Nacalai Tesque, Kyoto, Japan) and further cultured at $37^{\circ} \mathrm{C}$ in a humidified

372 atmosphere with $5 \% \mathrm{CO}_{2}$. The culture media were changed every 3 days.

\subsection{Immunocytochemical analysis of cultured undifferentiated spermatogonia}

Immunocytochemical analysis on freshly isolated or cultured cells was performed as described previously (Kim, Fujihara, Sahare, Minami, Yamada, \& Imai, 2014) . Briefly, the cells were fixed with 4\% paraformaldehyde, permeabilized, blocked, and incubated with the appropriate primary and secondary antibodies indicated below.

The following antibodies and dilutions were used: anti-DBA conjugated with fluorescein

380 isothiocyanate (FITC) (1: 200; Vector Laboratories, Burlingame, CA, USA), anti-GFR $\alpha-1$

381 (1:200; Santa Cruz Biotechnology, Santa Cruz, CA, USA), anti-UCHL-1 (PGP 9.5; 1:200;

Santa Cruz Biotechnology), anti-SOX2 (1:200; Santa Cruz Biotechnology), and anti-GATA4 (1:200, Santa Cruz Biotechnology). All primary antibodies were incubated with the specimens overnight at $4^{\circ} \mathrm{C}$. Then, the cells were washed three times with TBST (Sigma), incubated with the appropriate secondary antibodies - either Alexa Fluor 488 goat anti-rabbit IgG (Invitrogen) or Alexa Fluor 594 rabbit anti-goat (Invitrogen)—for $1 \mathrm{~h}$ at room temperature, and washed 
three more times with TBST. The nuclei were counterstained with Hoechst 33342 (Sigma), and the specimens were mounted in 50\% glycerol. Samples were observed under an immunofluorescence microscope (BX 50; Olympus, Tokyo, Japan).

\subsection{RT-PCR}

RNA was isolated from either freshly isolated testicular cells or cultured cells using TRIzol reagent (Ambion, Austin, TX, USA) according to the manufacturer's instructions. cDNA synthesis was performed using $1 \mu \mathrm{g}$ of total RNA per $20 \mu \mathrm{L}$ of PCR reaction mixture. Briefly, oligo(dT) primers were added to the isolated RNA and incubated for $5 \mathrm{~min}$ at $65^{\circ} \mathrm{C}$. ReverTra Ace (Toyobo, Tokyo, Japan) was added to the RNA mixture for the reverse transcriptase reaction. The samples were incubated for 60 minat $42^{\circ} \mathrm{C}$ followed by 5 min at $99^{\circ} \mathrm{C}$. performed using $1 \mu \mathrm{L}$ of cDNA per $20 \mu \mathrm{L}$ of PCR reaction mixture containing $2 \mathrm{mM} \mathrm{MgCl}_{2}$, $0.25 \mathrm{mM}$ dNTPs, $1 \mathrm{x}$ PCR buffer, 5 pmol of each primer and $1 \mathrm{U}$ of Taq DNA polymerase (ExTaq; TaKaRa, Tokyo, Japan). The primer sequences used for the amplification of specific genes are listed in Table 2. The PCR products were separated and visualized on $2 \%(\mathrm{w} / \mathrm{v})$ agarose gels containing ethidium bromide.

\subsection{Karyotype analysis}

Karyotype analysis was performed using a previously described protocol (Campos,

407 Sartore, Abdalla, \& Rehen, 2009) . Cultured cells were incubated in $0.1 \mu \mathrm{g} / \mathrm{ml}$ KaryoMAX using $0.25 \%$ trypsin-EDTA solution. Metaphase spreads were prepared by incubating single-cell

410 suspensions in a prewarmed $\left(37^{\circ} \mathrm{C}\right)$ hypotonic solution $(\mathrm{KCl} 75 \mathrm{mM})$ for 15 minutes and fixed

411 in 3:1 (methanol (Wako):glacial acetic acid (Sigma)) fixative solutions overnight at $4^{\circ} \mathrm{C}$. 
412 Chromosomes were stained with VECTASHIELD mounting medium with DAPI (Vector) and

413 observed under an immunofluorescence microscope (BX 50; Olympus, Tokyo, Japan). Thirty

414 metaphase spreads from three independent cell lines were counted.

415

$416 \quad 4.11$ Aggregation of cell lines with bovine embryos

417 Bovine 1-cell embryos at $20 \mathrm{~h}$ post-insemination (hpi) and produced in vitro as 418 described elsewhere (Ikeda, Kawahara-Miki, Iwata, Sugimoto, \& Kume, 2017) were treated 419 with pronase solution $(0.5 \%[\mathrm{w} / \mathrm{v}]$ in PBS) to remove the zona pellucida. The zona-free 1-cell 420 embryos were individually allocated to a well-of-the-well system (Vajta et al., 2008) using the 421 LinKID micro25 culture dish (Dai Nippon Printing) with $50 \mu \mathrm{L}$ of modified synthetic oviduct 422 fluid (mSOF) and cultured until 70 hpi. At 70 hpi, only the embryos that had developed to the 8-cell to 16-cell stages were left, and the culture medium was replaced with mSOF containing 5\% (v/v) KSR, bLIF-conditioned medium (1:1000 dilution), and $20 \mathrm{ng} / \mathrm{ml} \mathrm{GDNF.}$

Cell lines were tagged with $0.1 \mu \mathrm{L}$ of Vybrant CFDA SE cell tracer dye (Invitrogen) according to the manufacturer's instructions. Subsequently, 10 to 20 cells from each of three independent cell lines were transferred to zona-free embryos at the 8-cell to 16-cell stages. After four to five days in culture, the embryos were observed under a fluorescence microscope. For subsequent examination, embryos were fixed with 4\% PFA, prepared on slides, and counterstained with Hoechst 33342 (Sigma).

\subsection{Statistical analysis}

Pairwise comparisons of group means were conducted using Student's t-test. Multiple test. 
437

438

439

440

441

442

443

444

445

446

447

448

449

450

451

452

453

454

455

456

457

\section{Acknowledgements}

We thank Dr. K. Mukojima of the Gifu Prefectural Livestock Research Institute for providing adult testes, and we thank Dr. Y. Hoshino, Mr. H. Yoshioka, and Ms. E. Itoyama of the Kyoto University Livestock Farm for providing immature testes. We also thank Drs. Gabriela Durcova-Hills and Dr. Sandeep Goel for discussion and critical reading of the manuscript.

\section{References}

Aponte, P.M., Soda, T., van de Kant, H.J.G., \& de Rooij, D.G. (2006). Basic features of bovine spermatogonial culture and effects of glial cell line-derived neurotrophic factor. Theriogenology 65, 1828-1847.

Azizi, H., Conrad, S., Hinz, U., Asgari, B., Nanus, D., Peterziel, H., Hajizadeh Moghaddam, A., Baharvand, H., \& Skutella, T. (2016). Derivation of Pluripotent Cells from Mouse SSCs Seems to Be Age Dependent. Stem Cells International, 8216312, https://doi.org/10.1155/2016/8216312.

Campos, P.B., Sartore, R.C., Abdalla, S.N., \& and Rehen, S.K. (2009). Chromosomal spread preparation of human embryonic stem cells for karyotyping. Journal of Visualized Experiments, no. 31, https://doi.org/10.3791/1512.

Costa, G.M.J., Avelar, G.F., Rezende-Neto, J.V., Campos-Junior, P.H.A., Lacerda, S.M.S.N., Andrade, B.S.C., Thomé, R.G., Hofmann, M.-C., and Franca, L.R. (2012). Spermatogonial Stem Cell Markers and Niche in Equids. PLOS ONE 7 (8): e44091. https://doi.org/10.1371/journal.pone.0044091.

458 de Rooij, DG. 2001. Proliferation and Differentiation of Spermatogonial Stem Cells. 459 Reproduction $121(3): 347-54$. 
460 Fujihara, M., Kim, S.-M., Minami, N., Yamada, M., and Imai, H. (2011). Characterization and 461 in vitro culture of male germ cells from developing bovine testis. Journal of Reproduction and 462 Development, 57, 355-364.

463 Goel, S., Sugimoto, M., Minami, N., Yamada, M., Kume, S., and Imai, H. (2007). Identification, 464 Isolation, and In Vitro Culture of Porcine Gonocytes. Biology of Reproduction, 77, 127-137.

465 Goel, S., Reddy, N., Mandal, S., Fujihara, M., Kim, S.-M., and Imai, H. (2010). 466 Spermatogonia-specific proteins expressed in prepubertal buffalo (Bubalus bubalis) testis and 467 their utilization for isolation and in vitro cultivation of spermatogonia. Theriogenology, 74, $468 \quad 1221-1232$.

469 Golestaneh, N., Beauchamp, E., Fallen, S., Kokkinaki, M., Üren, A., and Dym, M. (2009). Wnt 470 signaling promotes proliferation and stemness regulation of spermatogonial stem/progenitor 471 cells. Reproduction, 138, 151-162.

472 Guan, K., Nayernia, K., Maier, L.S., Wagner, S., Dressel, R., Lee, J.H., Nolte, J., Wolf, F., Li, 473 M., Engel, W., Hasenfuss, G.. (2006). Pluripotency of spermatogonial stem cells from adult 474 mouse testis. Nature, 440, 1199-1203.

475 Hasegawa, K., Namekawa, S.H., and Saga, Y. (2013). MEK/ERK signaling directly and 476 indirectly contributes to the cyclical self-renewal of spermatogonial stem cells. Stem Cells, 31, $477 \quad 2517-2527$.

478 Heidari, B., Rahmati-Ahmadabadi, M., Akhondi, M.M., Zarnani, A.H., Jeddi-Tehrani, M., 479 Shirazi, A., Naderi, M.M., and Behzadi, B. (2012). Isolation, identification, and culture of goat 480 spermatogonial stem cells using c-kit and PGP9.5 markers. Journal of Assisted Reproduction 481 and Genetics, 29, 1029-1038. 
482 Herrid, M., Davey, R.J., and Hill, J.R. (2007). Characterization of germ cells from pre-pubertal 483 bull calves in preparation for germ cell transplantation. Cell and Tissue Research, 330, 321484329.

485 Ikeda, S., Kawahara-Miki, R., Iwata, H., Sugimoto, M., and Kume, S. (2017). Role of 486 methionine adenosyltransferase $2 \mathrm{~A}$ in bovine preimplantation development and its associated 487 genomic regions. Scientific Reports, 7, 3800.

Izadyar, F., Spierenberg, G.T., Creemers, L.B., den Ouden, K., and de Rooij, D.G. (2002). Isolation and purification of type A spermatogonia from the bovine testis. Reproduction, 124, 85-94.

491 Kanatsu-Shinohara, M., Ogonuki, N., Inoue, K., Miki, H., Ogura, A., Toyokuni, S., and

492 Shinohara, T. (2003). Long-term proliferation in culture and germline transmission of mouse 493 male germline stem cells. Biology of Reproduction, 69, 612-616.

494 Kanatsu-Shinohara, M., Inoue, K., Lee, J., Yoshimoto, M., Ogonuki, N., Miki, H., Baba, S., 495 Kato, T., Kazuki, Y., Toyokuni, S., et al. (2004). Generation of Pluripotent Stem Cells from 496 Neonatal Mouse Testis. Cell, 119, 1001-1012.

497 Kanatsu-Shinohara, M., Kato, M., Takehashi, M., Morimoto, H., Takashima, S., Chuma, S., 498 Nakatsuji, N., Hirabayashi, M., and Shinohara, T. (2008). Production of transgenic rats via 499 lentiviral transduction and xenogeneic transplantation of spermatogonial stem cells. Biology of 500 Reproduction, 79, 1121-1128.

501 Kawaguchi, T., Tsukiyama, T., Kimura, K., Matsuyama, S., Minami, N., Yamada, M., and 502 Imai, H. (2015). Generation of naïve bovine induced pluripotent stem cells using piggyBac transposition of doxycycline-inducible transcription factors. PLOS ONE, 10, e0135403. 
504 Kim, S.-M., Fujihara, M., Sahare, M., Minami, N., Yamada, M., and Imai, H. (2014). Effects

505 of extracellular matrices and lectin Dolichos biflorus agglutinin on cell adhesion and self-

506 renewal of bovine gonocytes cultured in vitro. Reproduction, Fertility and Development, 26,

$507 \quad 268-281$.

508 Ko, K., Tapia, N., Wu, G., Kim, J.B., Bravo, M.J.A., Sasse, P., Glaser, T., Ruau, D., Han, D.W.,

509 Greber, B., et al. (2009). Induction of pluripotency in adult unipotent germline stem cells. Cell

510 Stem Cell, 5, 87-96.

511 Kubota, H., Avarbock, M.R., and Brinster, R.L. (2003). Spermatogonial stem cells share some,

512 but not all, phenotypic and functional characteristics with other stem cells. Proceedings of the

513 National Academy of Sciences, USA., Proc. Natl. Acad. Sci. 100, 6487-6492.

514 Lee, K.H., Lee, W.Y., Kim, J.H., Yoon, M.J., Kim, N.H., Kim, J.H., Uhm, S.J., Kim, D.H.,

515 Chung, H.J., and Song, H. (2013). Characterization of GFR $\alpha$-1-positive and GFR $\alpha$-1-negative

516 spermatogonia in neonatal pig testis. Reproduction in Domestic Animals, 48, 954-960.

517 Li, B., Zhuang, M., Wu, C., Niu, B., Zhang, Z., Li, X., Wei, Z., Li, G., and Hua, J. (2016).

518 Bovine male germline stem-like cells cultured in serum- and feeder-free medium.

519 Cytotechnology, 68, 2145-2157.

520 Li, C.-H., Yan, L.-Z., Ban, W.-Z., Tu, Q., Wu, Y., Wang, L., Bi, R., Ji, S., Ma, Y.-H., Nie, W.-

521 H., et al. (2017). Long-term propagation of tree shrew spermatogonial stem cells in culture and

522 successful generation of transgenic offspring. Cell Research, 27, 241-252.

523 Meng, X., Lindahl, M., Hyvönen, M.E., Parvinen, M., Rooij, D.G. de, Hess, M.W.,

524 Raatikainen-Ahokas, A., Sainio, K., Rauvala, H., Lakso, M., et al. (2000). Regulation of cell

525 fate decision of undifferentiated spermatogonia by GDNF. Science, 287, 1489-1493. 
526 Naughton, C.K., Jain, S., Strickland, A.M., Gupta, A., and Milbrandt, J. (2006). Glial cell-line

527 derived neurotrophic factor-mediated RET signaling regulates spermatogonial stem cell fate.

528 Biology of Reproduction, 74, 314-321.

529 Oatley, J.M., de Avila, D.M., Reeves, J.J., and McLean, D.J. (2004). Testis tissue explant

530 culture supports survival and proliferation of bovine spermatogonial stem cells. Biology of 531 Reproduction, 70, 625-631.

532 Oatley, M.J., Kaucher, A.V., Yang, Q.-E., Waqas, M.S., and Oatley, J.M. (2016). Conditions

533 for long-term culture of cattle undifferentiated spermatogonia. Biology of Reproduction, 95,

534 14. doi: 10.1095/bioreprod.116.139832.

535 Pramod, R.K., and Mitra, A. (2014). In vitro culture and characterization of spermatogonial 536 stem cells on Sertoli cell feeder layer in goat (Capra hircus). Journal of Assisted Reproduction 537 and Genetics, 31, 993-1001.

538 Reding, S.C., Stepnoski, A.L., Cloninger, E.W., and Oatley, J.M. (2010). THY1 is a conserved 539 marker of undifferentiated spermatogonia in the pre-pubertal bull testis. Reproduction 139, $540 \quad 893-903$.

541 Sahare, M., Otomo, A., Komatsu, K., Minami, N., Yamada, M., and Imai, H. (2015). The role 542 of signaling pathways on proliferation and self-renewal of cultured bovine primitive germ cells. 543 Reproductive Medicine and Biology, 14, 17-25.

544 Sahare, M., Kim, S.-M., Otomo, A., Komatsu, K., Minami, N., Yamada, M., and Imai, H. 545 (2016). Factors supporting long-term culture of bovine male germ cells. Reproduction Fertility 546 and Development, 28, 2039-2050. 
547 Sato, N., Meijer, L., Skaltsounis, L., Greengard, P., and Brivanlou, A.H. (2004). Maintenance

548 of pluripotency in human and mouse embryonic stem cells through activation of Wnt signaling

549 by a pharmacological GSK-3-specific inhibitor. Nature Medicine, 10, 55-63.

550 Seandel, M., James, D., Shmelkov, S.V., Falciatori, I., Kim, J., Chavala, S., Scherr, D.S., Zhang,

551 F., Torres, R., Gale, N.W., et al. (2007). Generation of functional multipotent adult stem cells

552 from GPR125+ germline progenitors. Nature, 449, 346-350.

553 Sun, F., Xu, Q., Zhao, D., and Chen, C.D. (2015). Id4 Marks Spermatogonial Stem Cells in the

554 Mouse Testis. Scientific Reports, 5, 17594.

555 Takase, H.M., and Nusse, R. (2016). Paracrine Wnt/ $\beta$-catenin signaling mediates proliferation

556 of undifferentiated spermatogonia in the adult mouse testis. Proceedings of the National

557 Academy of Sciences, USA., 113, E1489-1497.

558 Tegelenbosch, R.A., and de Rooij, D.G. (1993). A quantitative study of spermatogonial

559 multiplication and stem cell renewal in the C3H/101 F1 hybrid mouse. Mutation Research, 290, $560 \quad 193-200$.

561 Vajta, G., Korösi, T., Du, Y., Nakata, K., Ieda, S., Kuwayama, M., and Nagy, Z.P. (2008). The

562 Well-of-the-Well system: an efficient approach to improve embryo development. Reproductive

563 Biomedicine Online, 17, 73-81.

564 Zhang, P., Chen, X., Zheng, Y., Zhu, J., Qin, Y., Lv, Y., and Zeng, W. (2017). Long-term 565 propagation of porcine undifferentiated spermatogonia. Stem Cells Development, 26, 11215661131. 
567 Zheng, Y., Tian, X., Zhang, Y., Qin, J., An, J., and Zeng, W. (2013). In vitro propagation of

568 male germline stem cells from piglets. Journal of Assisted Reproduction and Genetics, 30, 945-

569952.

570 Zheng, Y., Zhang, Y., Qu, R., He, Y., Tian, X., and Zeng, W. (2014). Spermatogonial stem

571 cells from domestic animals: progress and prospects. Reproduction, 147, 65-74.

572

573

574

575

576

577

578

579

580

581

582

583

584 
(a)
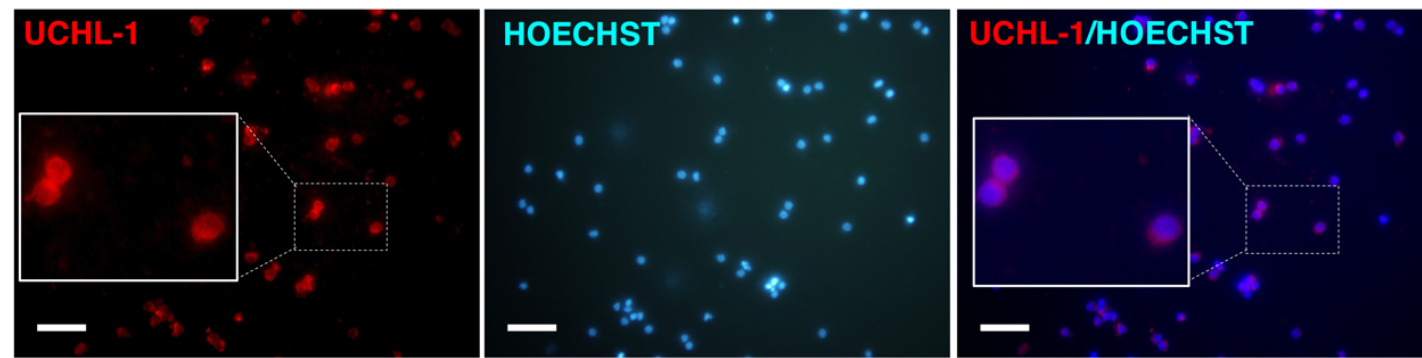

(b)
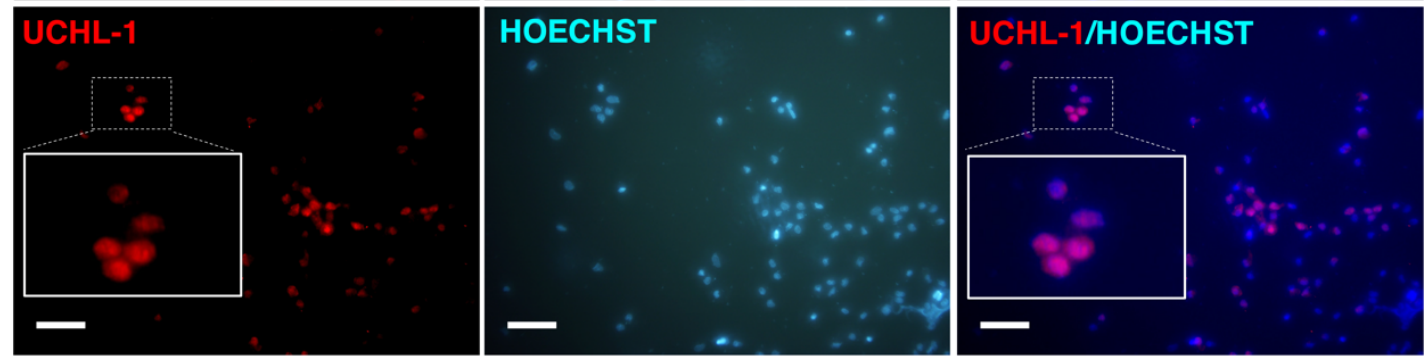

(c)

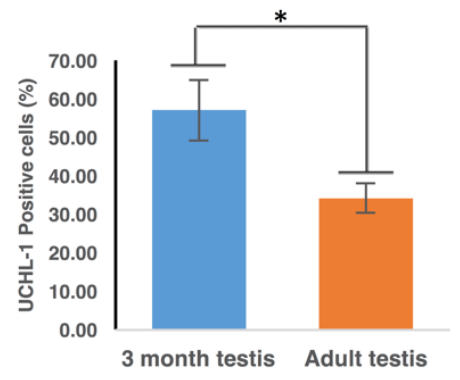

(d)

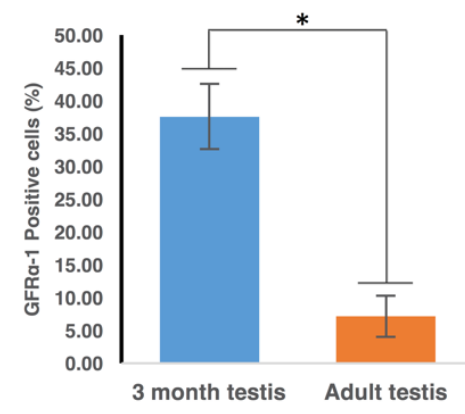

586 Figure 1. Differential expression of GFR $\alpha-1$ and UCHL-1 in cell suspensions

587 isolated from immature and adult testes after Percoll gradient centrifugation.

588 GFR $\alpha$-1-positive cells isolated from (a) 3-month-old bovine testes and from (b) adult

589 bovine testes. The percentages of (c) UCHL-1-positive and (d) GFR $\alpha$-1-positive cells

590 from 3-month-old and adult bovine testes. RT-PCR analysis of $U C H L-1$ expression in

591 germ cells isolated from 3-month-old or adult bovine testes (e). Higher magnifications are

592 shown in the inset. Scale bars represent $50 \mu \mathrm{m} . \mathrm{n}=6$. 
(a)
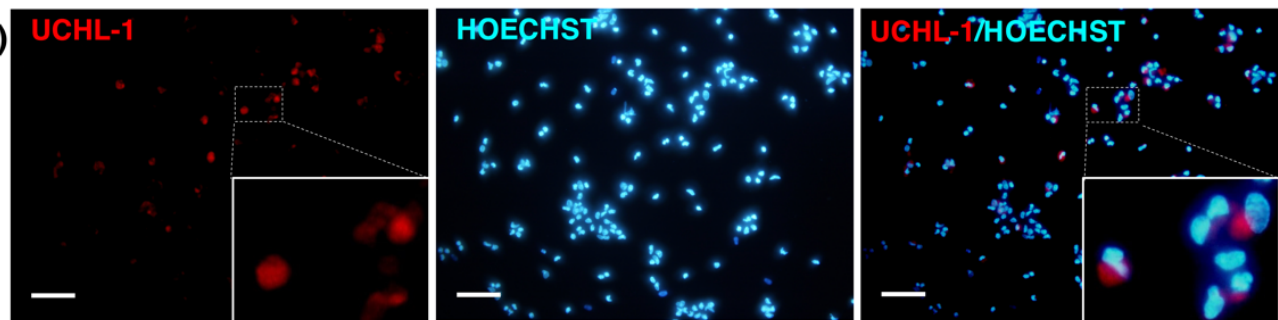

(b)
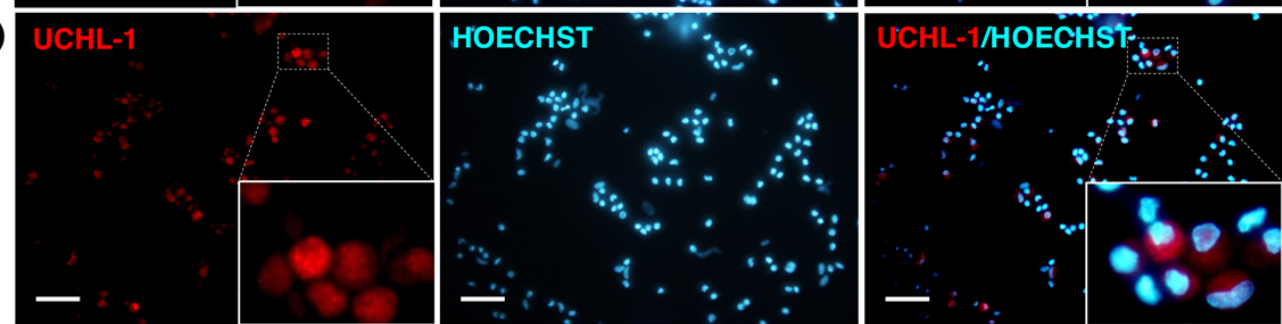

(c)
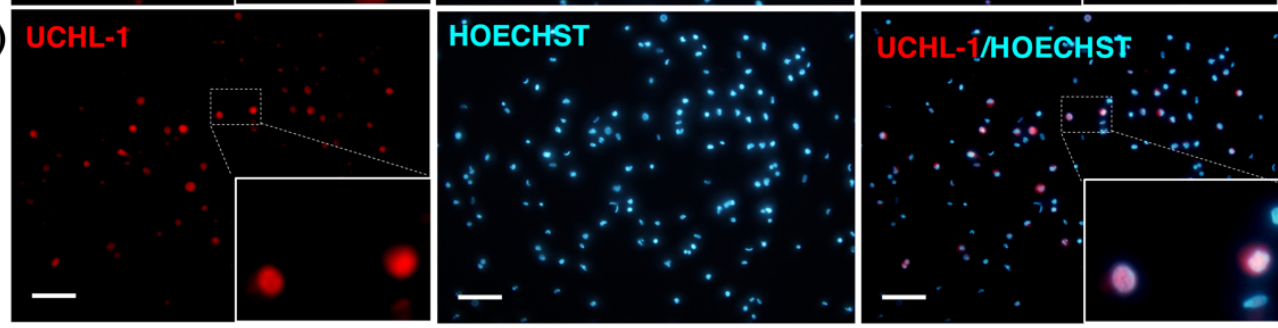

(d)

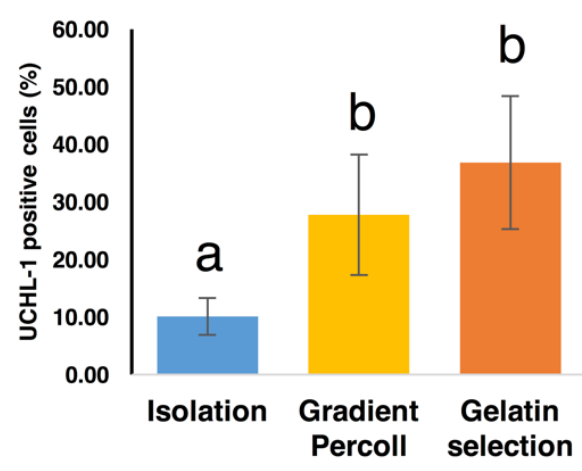

(ө) $\begin{array}{r}\quad 100.00 \\ \quad 90.00\end{array}$

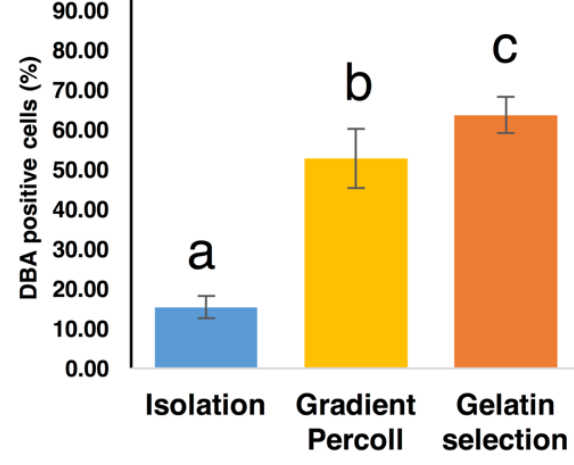

597 Figure 2. Enrichment for undifferentiated spermatogonia isolated from adult

598 testes. (a) - (e) show UCHL-1-positive cells in freshly isolated cell suspensions. (a)

599 UCHL-1-positive cells in the 20\% Percoll fraction, (b) UCHL-1-positive cells in the 40\%

600 Percoll fraction, and (c) UCHL-1-positive cells after gelatin selection. Enrichment (\%) for

601 undifferentiated spermatogonia was estimated as either (d) the number of UCHL-1

602 positive cells or (e) the number of DBA-positive cells. Higher magnifications are shown

603 in the inset. Scale bars represent $50 \mu \mathrm{m} . \mathrm{n}=4$. 
(a)
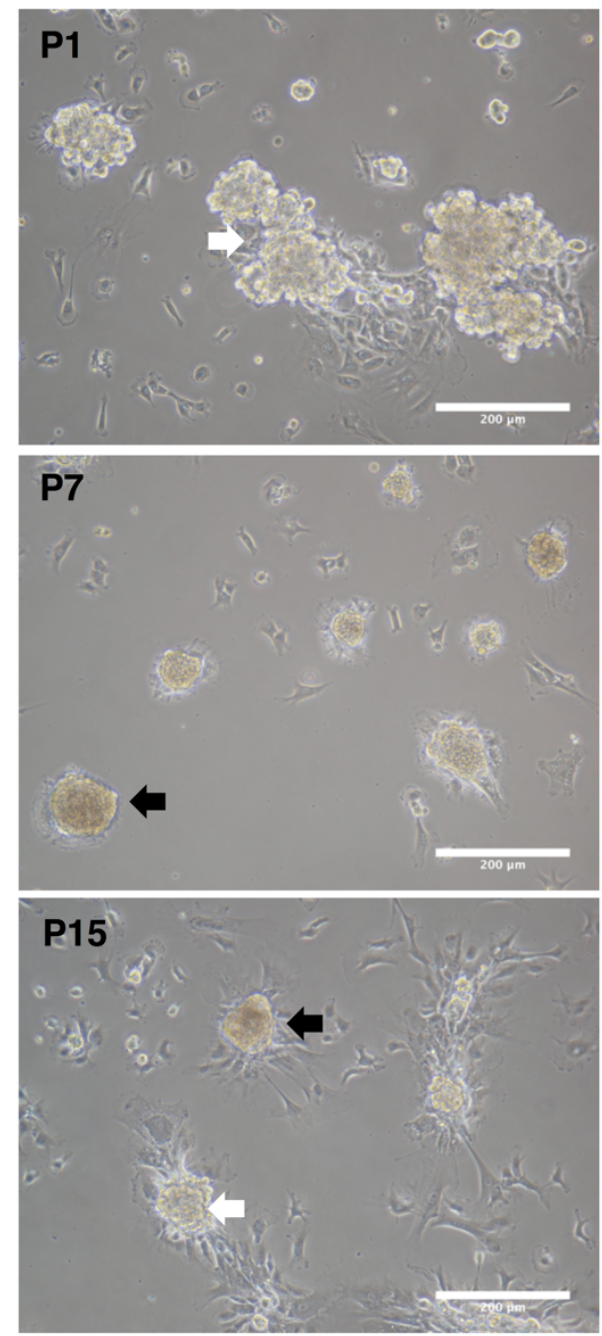

(b)

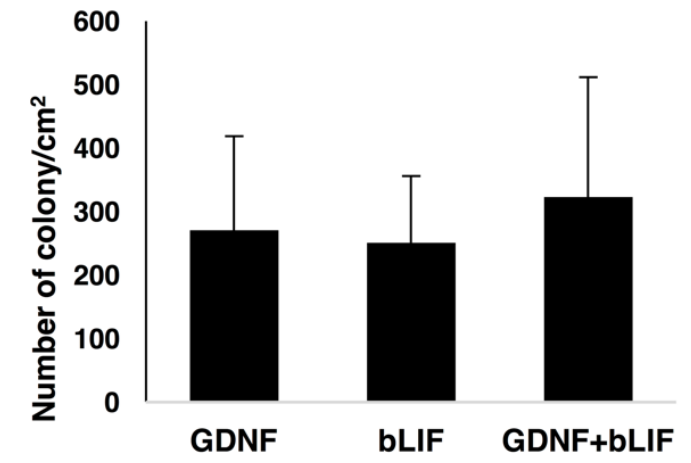

(c)
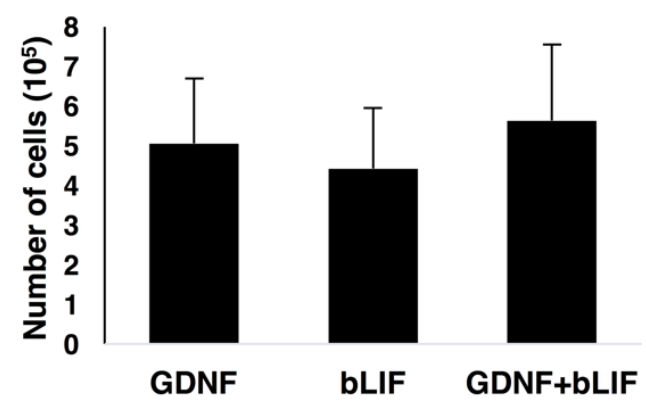

(d)

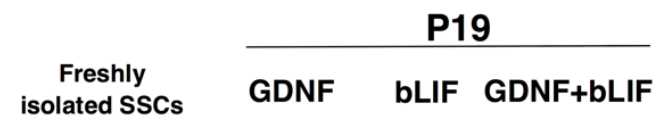

\section{$\beta-A C T I N$}

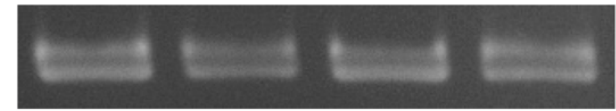

UCHL-1

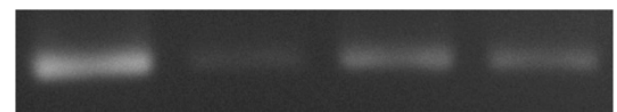

605 Figure 3. Colony formation of immature testis undifferentiated spermatogonia

606 cultured under different conditions. Undifferentiated spermatogonia isolated from

607 immature testes were cultured in medium containing GDNF, bLIF, or both. Morphology

608 of the colonies cultured in medium containing GDNF and bLIF. White arrows indicate

609 botryoidally aggregated colonies resembling GS cells, and black arrows indicate tightly

610 packed 3-dimensional colonies resembling ES-like cells (a). Number of colonies $/ \mathrm{cm}^{2}$ after

611 the first passage (P1) (b); total number of cells after P1 (c); RT-PCR analysis of $U C H L$ -

6121 at P19 in colonies cultured under different culture conditions (d). Scale bars represent $613200 \mu \mathrm{m}$. 


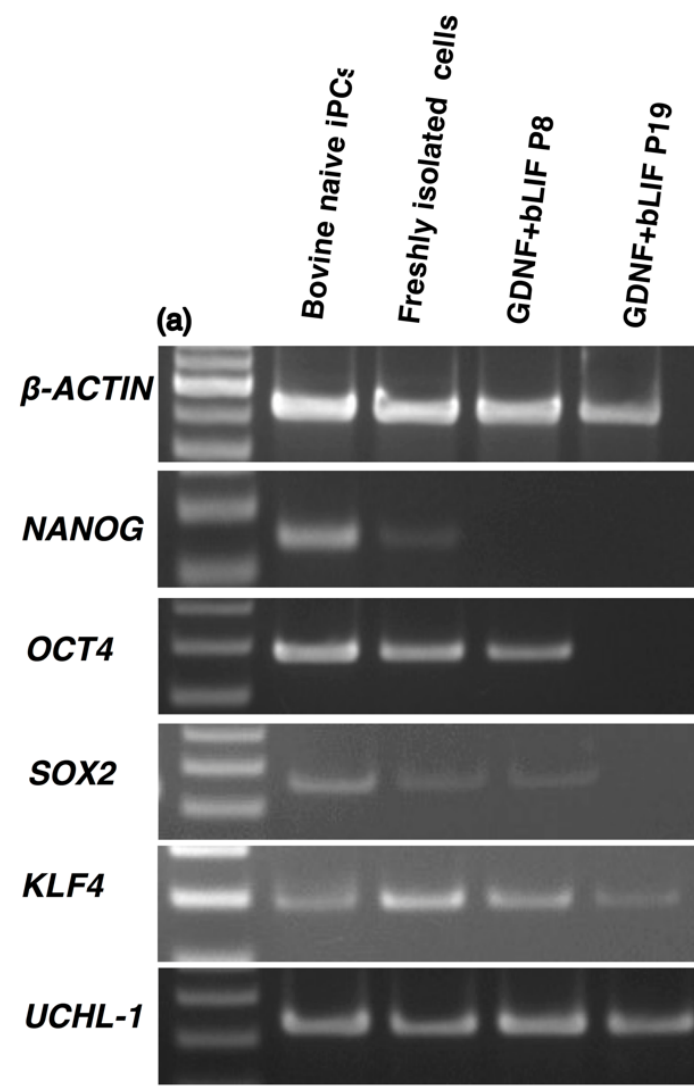

(c)

(b)
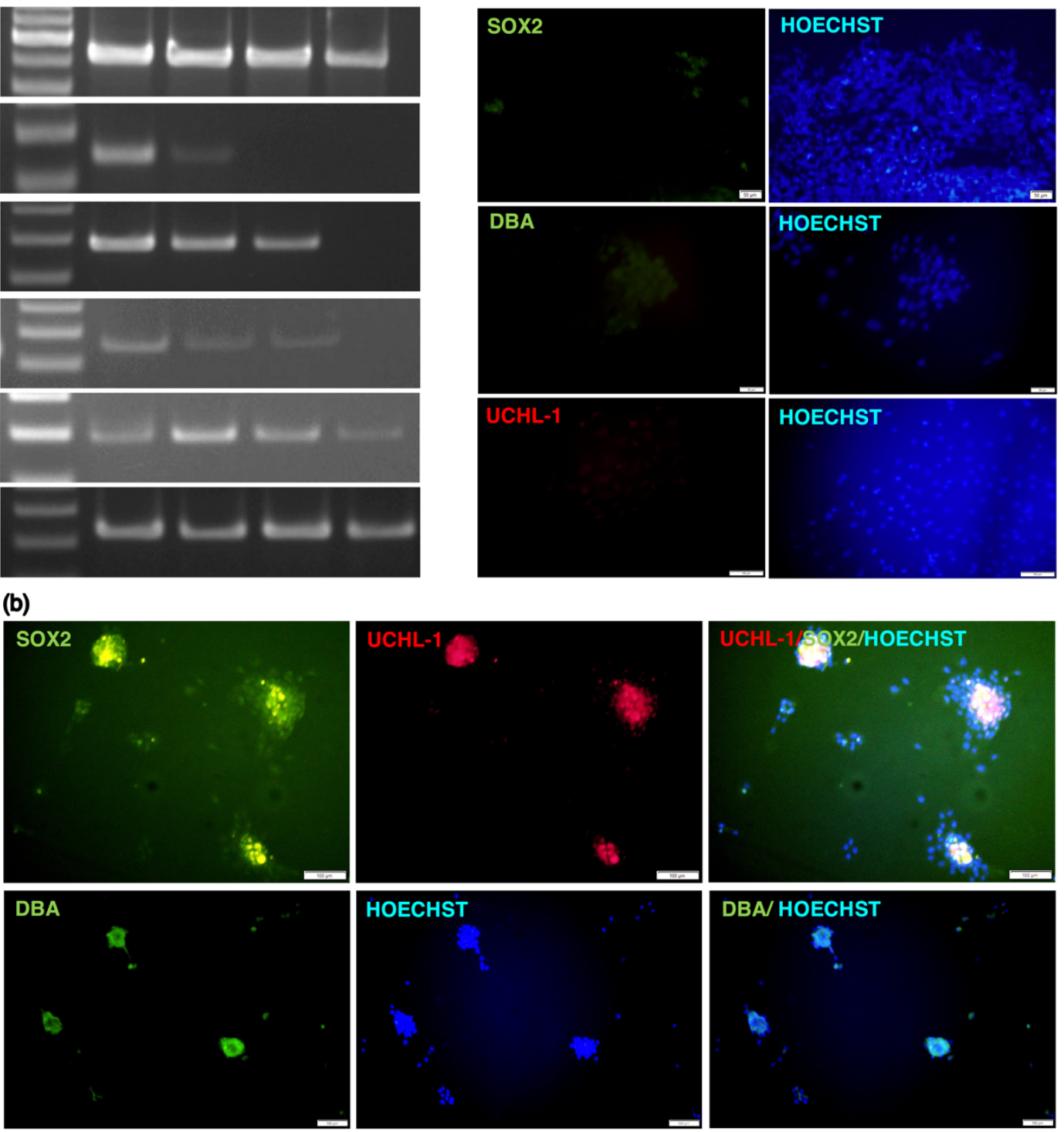

615 Figure 4. Characterization of cell lines from immature testis undifferentiated

616 spermatogonia cultured in medium containing GDNF and bLIF. RT-PCR analysis of

617 NANOG, OCT3/4, KLF4, SOX2 (stem cell markers) and UCHL-1 (a germ cell marker)

618 (a); immunofluorescence analysis of the expression of SOX-2, UCHL-1, and DBA (b);

619 STO feeder cells as negative control of immunofluorescence analysis (c). 
(a)
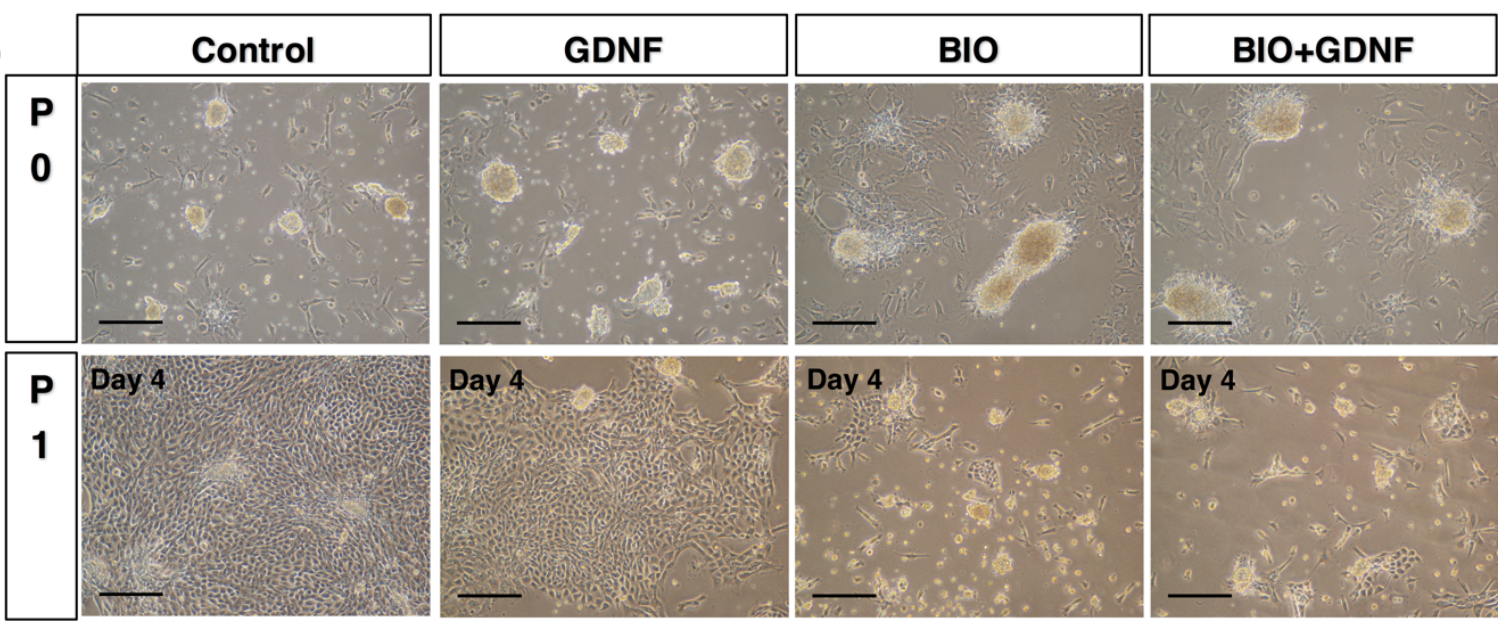

(b)

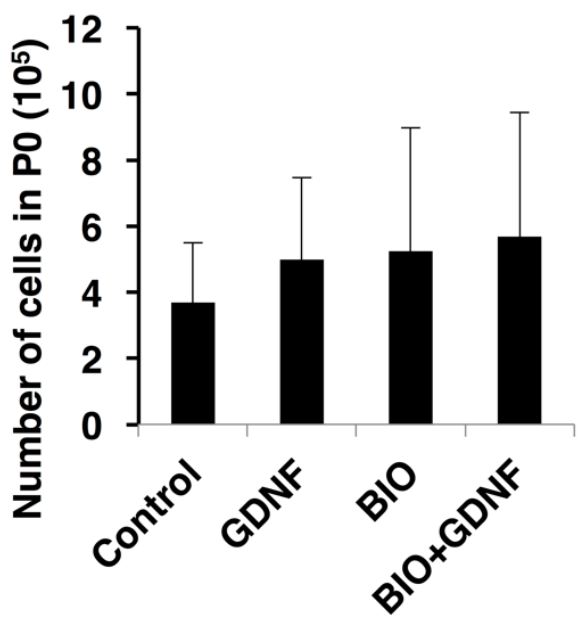

(c)

PO

Control GDNF BIO GDNF+BIO

620

$\beta-A C T I N$

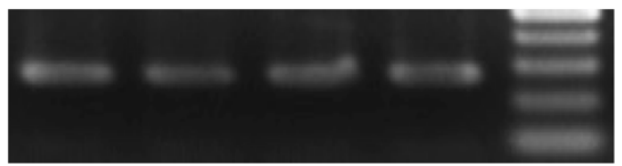

UCHL-1

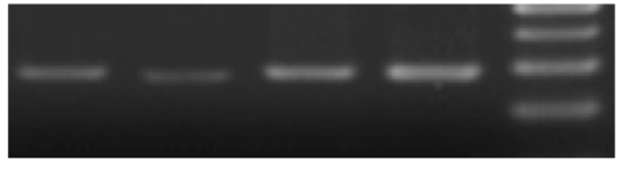

621 Figure 5. Colony formation of undifferentiated spermatogonia from adult testis under different culture conditions. Undifferentiated spermatogonia isolated from adult

623 testes were cultured in basic medium in the presence of GDNF, BIO, or both (a).

624 Colonies appeared in primary culture (P0) and at the first passage (P1); (b) the total 625 number of cells was counted at P0. (c) RT-PCR analysis of UCHL-1 expression in P0 626 colonies cultured under different culture conditions. Scale bars represent $100 \mu \mathrm{m}$. 
(a)

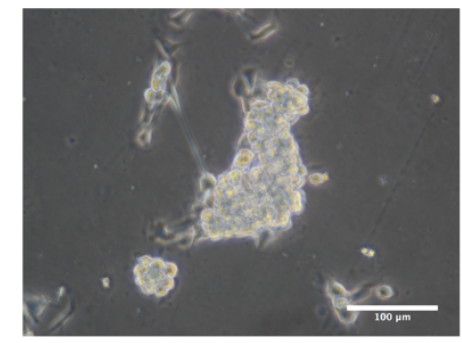

(b)

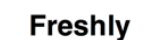

isolated cells P3 P8 P10

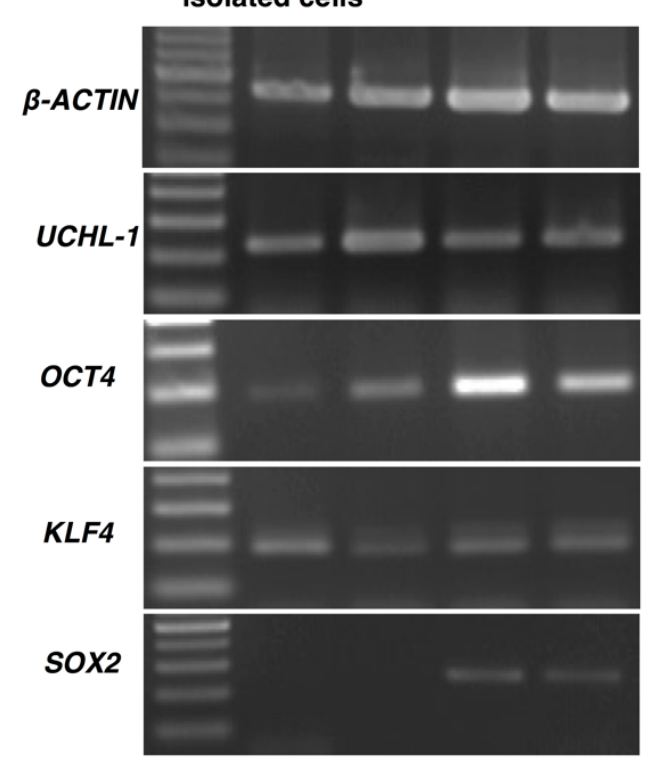

(c) DBA
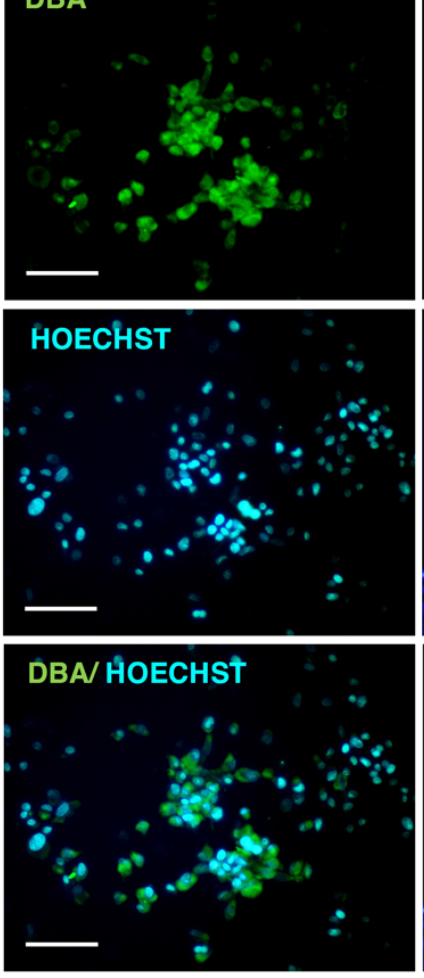

\section{GFRa-1}

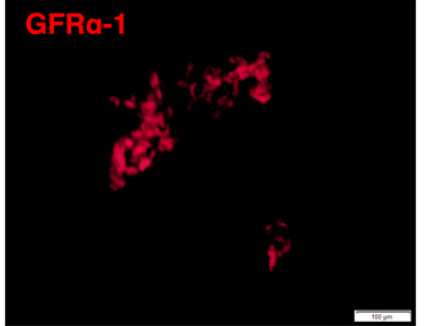

HOECHST

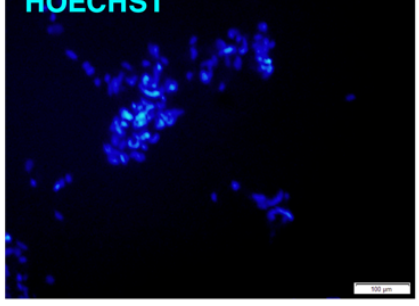

GFRa-1/HOECHST

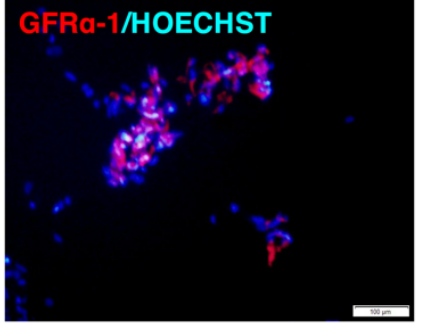

630

631 Figure 6. Characterization of undifferentiated spermatogonia colonies in the

632 presence of BIO. (a) A typical GS cell colonies at P10. (b) RT-PCR analysis of $U C H L$ -

$6331, O C T 3 / 4, K L F 4$, and SOX2 at P3, P8, and P10. (c) Immunofluorescence analysis of

634 DBA and GFR $\alpha-1$ expression.

635

636

637

638 
(a)
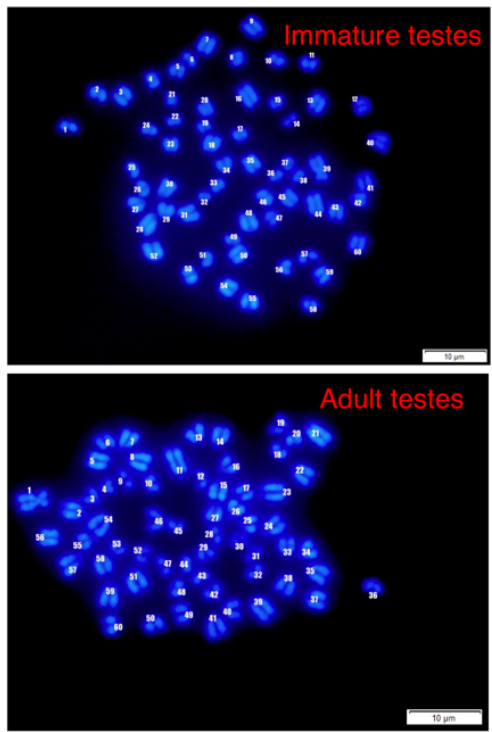

(b)

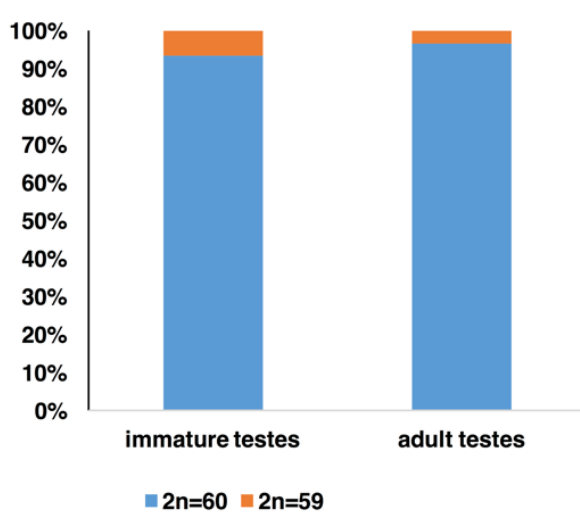

(c)

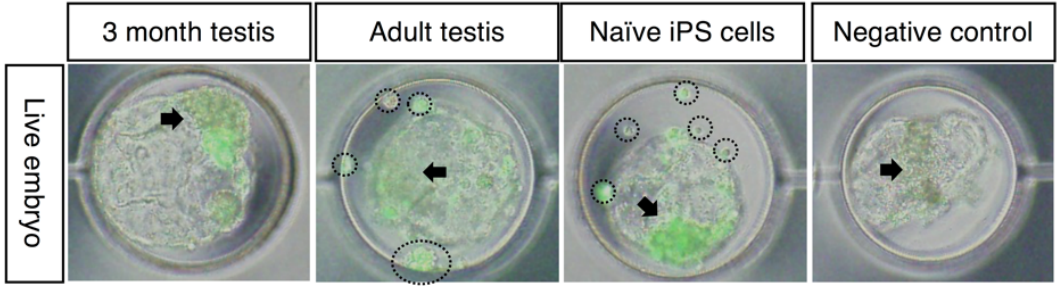

640

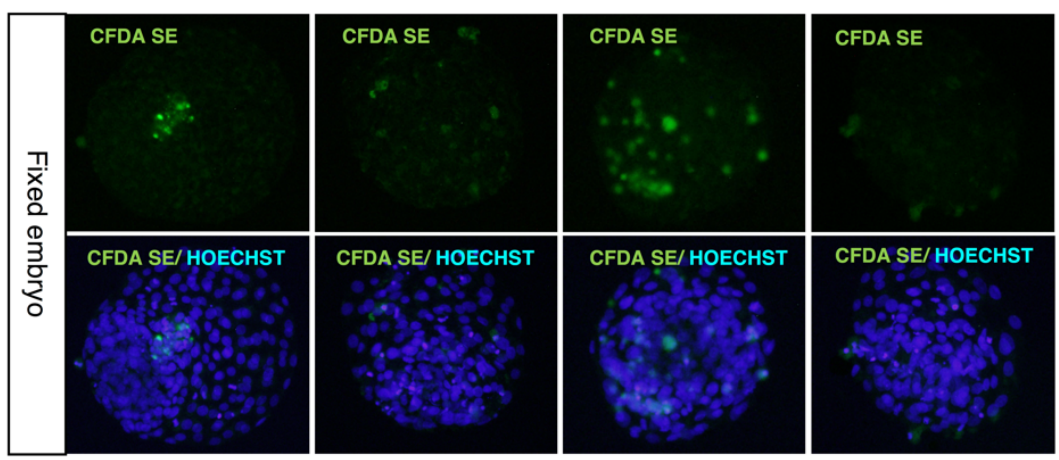

641 Figure 7. Characterization of undifferentiated spermatogonia-derived cell

642 lines from both immature and adult testes. (a) Karyotyping image of cells from

643 immature and adult testis cell lines at passages 12 and 14. (b) Percentage of cells with

644 normal chromosome number $(n=30)$. (c) Cell lines from both immature and adult testes

645 tagged with CFDA SE cell tracker were aggregated with host 8- to 16-cell in vitro

646 fertilized embryos; naïve-type bovine iPS cells and embryos only were used as positive

647 and negative controls, respectively. Black dashed circles indicated non-integrated cells;

648 black arrows indicate the inner cell mass (ICM). 
649 Table 1. Aggregation of undifferentiated spermatogonia derived cell lines into in vitro fertilized

650 bovine embryos

\begin{tabular}{|c|c|c|c|c|c|}
\hline \multirow[b]{2}{*}{ Donor cells } & \multirow[b]{2}{*}{$\begin{array}{c}\text { No. of } \\
\text { aggregated } \\
\text { embryos }\end{array}$} & \multirow[b]{2}{*}{$\begin{array}{l}\text { No. of blastocysts } \\
\text { developed }\end{array}$} & \multicolumn{3}{|c|}{ Chimeric blastocysts } \\
\hline & & & $\begin{array}{l}\text { No. integrated } \\
\text { to ICM }(\%)\end{array}$ & $\begin{array}{l}\text { No. integrated } \\
\text { to both ICM } \\
\text { and TE (\%) }\end{array}$ & $\begin{array}{l}\text { No. integrated } \\
\text { to TE }(\%)\end{array}$ \\
\hline 3 month testes & 37 & $15(40.54)$ & $4(26.67)$ & $0(0.00)$ & $0(0.00)$ \\
\hline Adult testes & 35 & $13(37.14)$ & $0(0.00)$ & $0(0.00)$ & $2(15.38)$ \\
\hline Freshly isolated cells & 13 & $5(38.46)$ & $0(0.00)$ & $0(0.00)$ & $0(0.00)$ \\
\hline BEF & 19 & $8(42.11)$ & $0(0.00)$ & $0(0.00)$ & $0(0.00)$ \\
\hline Naïve-type bovine iPSCs & 14 & $7(50.00)$ & $1(14.29)$ & $6(85.71)$ & $0(0.00)$ \\
\hline Embryo only & 19 & $10(52.63)$ & $0(0.00)$ & $0(0.00)$ & $0(0.00)$ \\
\hline
\end{tabular}

651

652

653

654

655

656

657

658

659

660

661

662 
663 Table 2. Primer sequences used in this experiment

\begin{tabular}{lll}
\hline \multirow{2}{*}{ Gene name } & \multicolumn{2}{c}{ Primer sequence (5' - 3') } \\
\cline { 2 - 3 } Forward & \multicolumn{1}{c}{ Reverse } \\
\hline$U C T H-1$ & ACCCCGAGATGCTGAACAAAG & CCCAATGGTCTGCTTCATGAA \\
$S O X 2$ & AGAGAAAGCGGACGAGTAT & AGTACAGAGTAGTGAAGTGAGG \\
$K L F 4$ & TTACCTCTTCTTCCCACTCC & TTCTTGCTGTCCTCCATTTC \\
$C-K I T$ & CCCACACAGGTGAGAAACCT & ATGTGTAAGGCGAGGTGGTC \\
$S T R A 8$ & GACCTGGAGGACTTGCTGAG & AGGGGCTGCTTCCTAAAGAG \\
$S Y C P 3$ & TGACTTTGTTCCAGCAGTGG & ACTTTCGGACACTTGCCATC \\
$\beta-A C T I N$ & TCCCTGGAGAAGAGCTACGA & ACATCTGCTGGAAGGTGGAC \\
\hline
\end{tabular}

664

665

666

667

668

669

670

671

672

673

674

675

676

677 
678 Supporting information

679
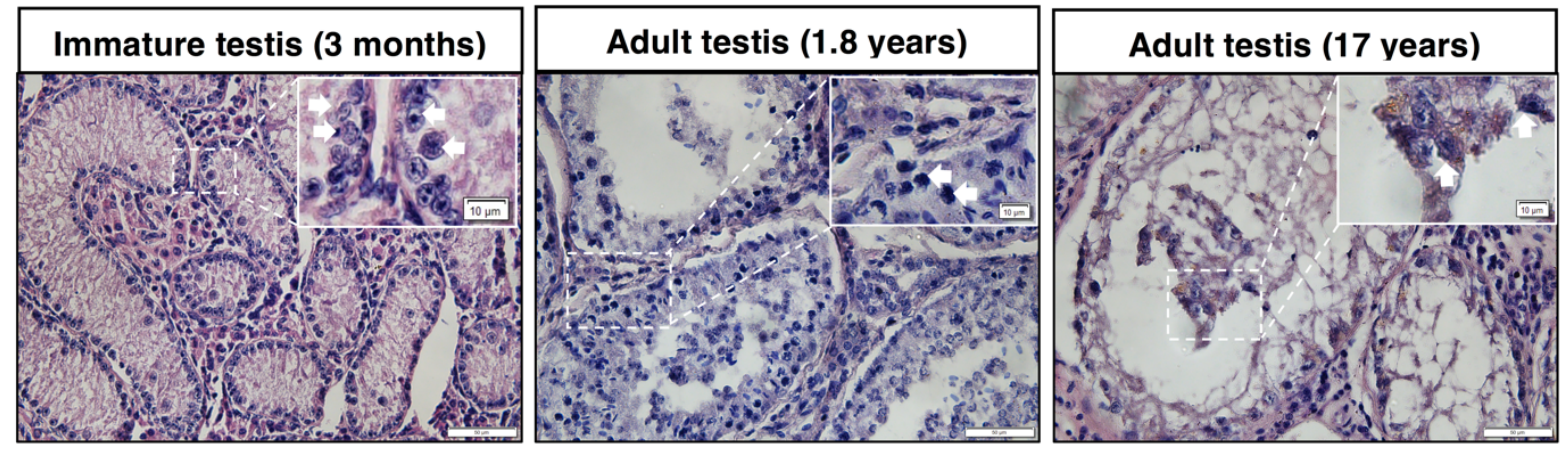

680 Figure S1. Histology of the testes. Hematoxylin and eosin staining shows germ cells in the

681 seminiferous tubules of testes from immature (3-month-old) and adult (1.8-year-old and 17-

682 year-old) cattle.

683

684

685

686

687

688

689

690

691

692

693 
(a)
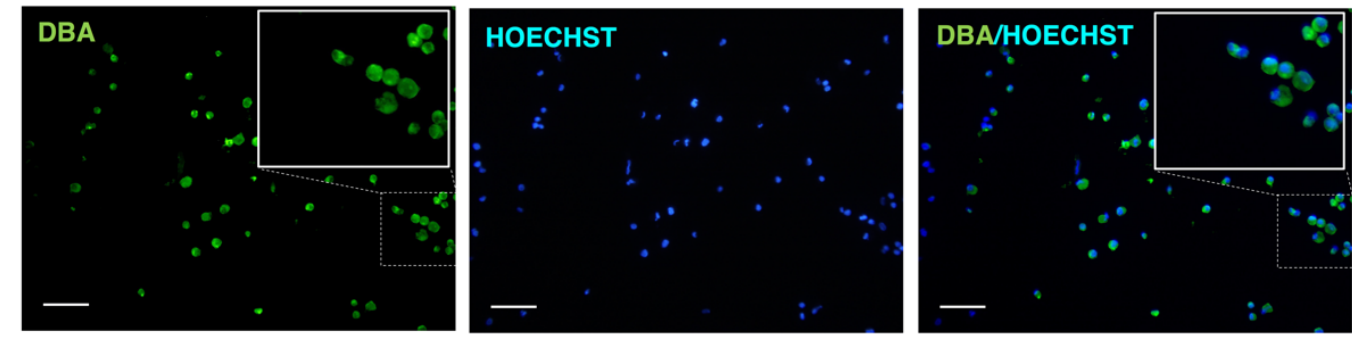

(b)
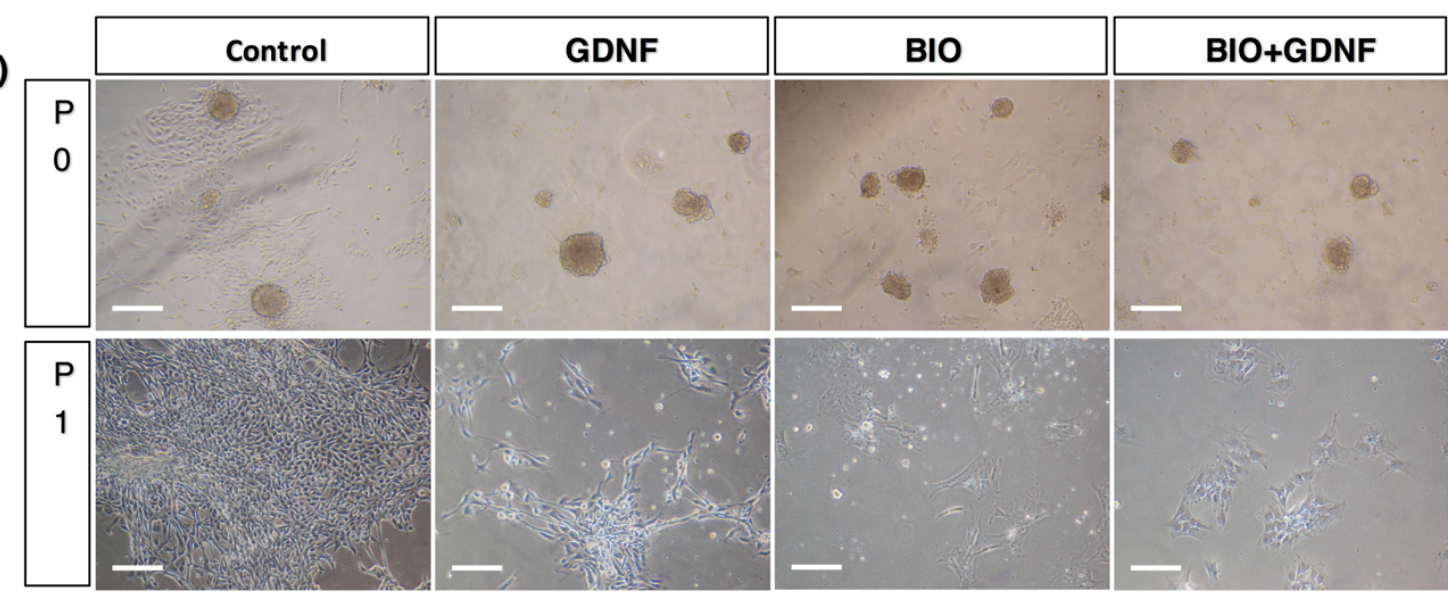

695 Figure S2. Germ cells isolated from the testis of a 1.4-year-old bovine. DBA-positive germ

696 cells isolated from the 1.4-year-old bovine testis in the $40 \%$ Percoll fraction after gelatin

697 selection (a); morphology of germ cell colonies collected from the $40 \%$ Percoll fraction.

698 Isolated cells were cultured in the basic medium (control) and in the presence of GDNF, BIO,

699 and a combination of BIO and GDNF (b). Colony formation was examined in primary culture

$700 \quad(\mathrm{P} 0)$ and after the first passage (P1).

701

702

703

704 
(a)

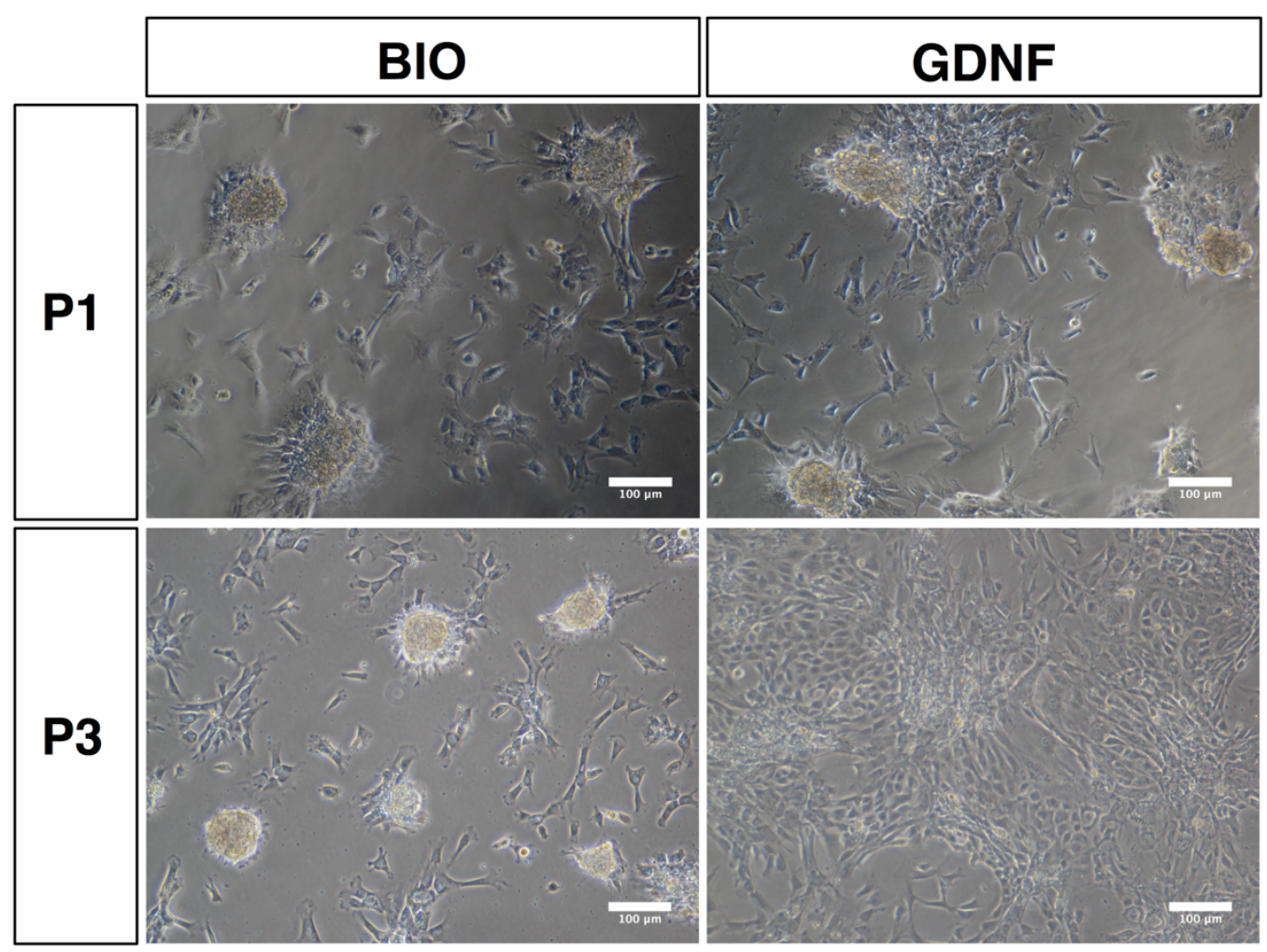

Isolated

P2

(b)

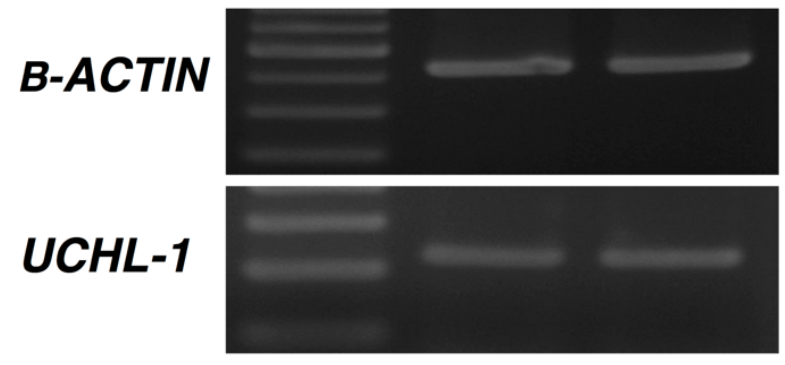

706

707 Figure S3. Undifferentiated spermatogonia isolated from the testis of a 17-year-old bovine.

708 Undifferentiated spermatogonia colonies after passages 1 and 3 in the presence of GDNF or

709 BIO (a); RT-PCR gene expression analysis of the germ cell marker $U C H L-1$ was examined in

710 colonies at passage 2 in the presence of $\mathrm{BIO}(\mathrm{b})$.

711

712 

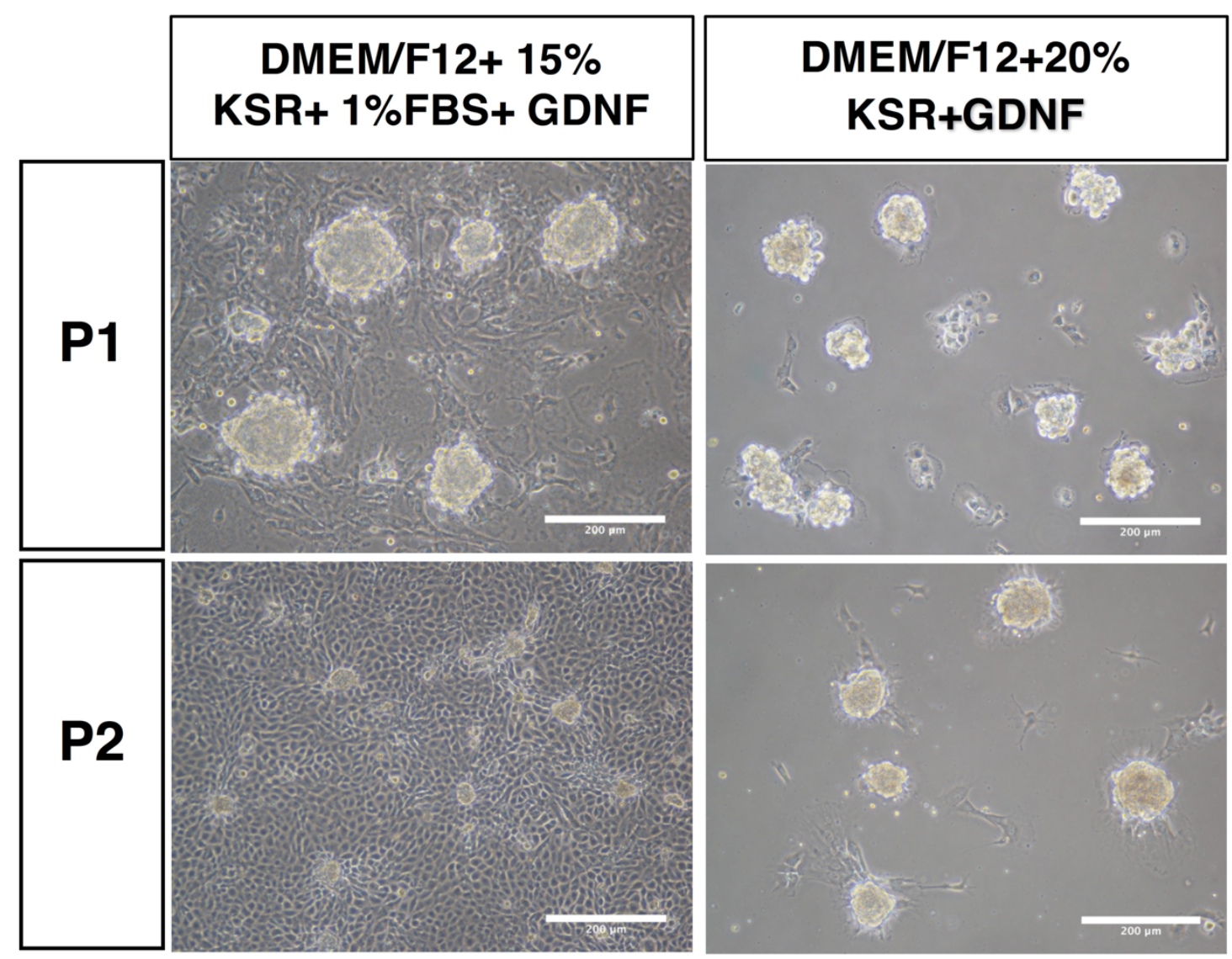

714 Figure S4. Undifferentiated spermatogonia colonies collected from immature bovine testes

715 cultured in the presence and absence of FBS at passage $1(\mathrm{P} 1)$ and $\mathrm{P} 2$. 
(a)

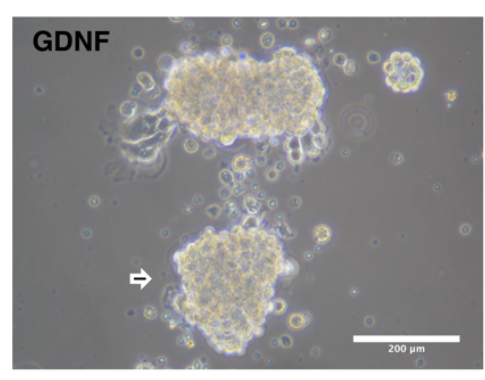

(b)
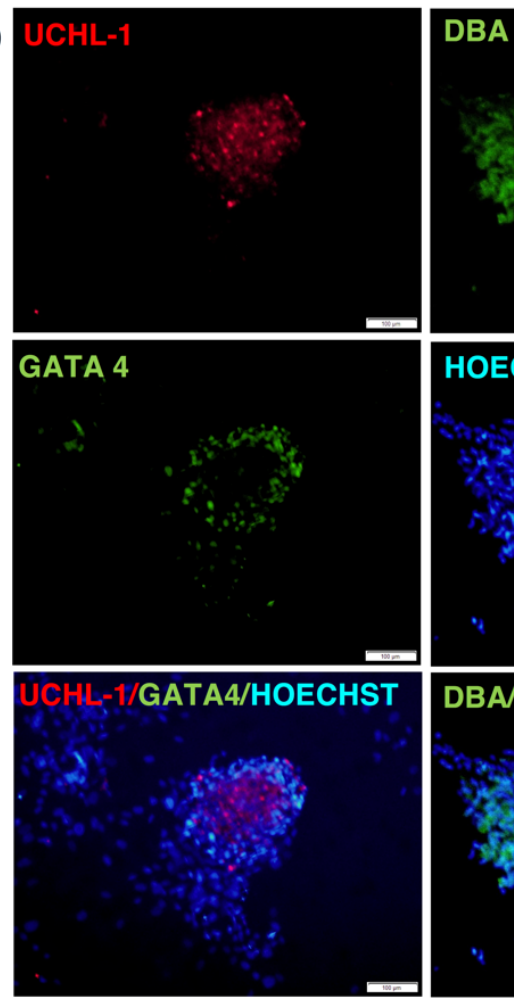

\section{DBA}

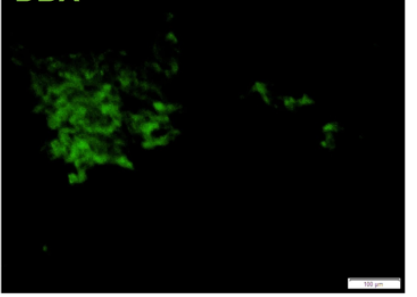

HOECHST

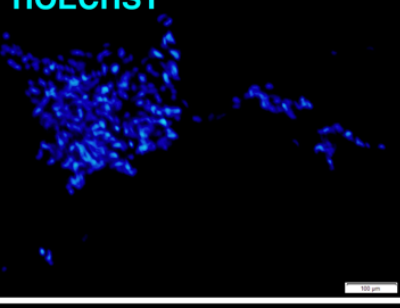

DBA/HOECHST

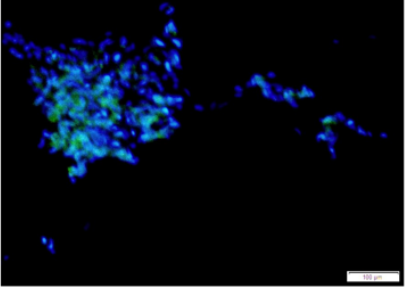

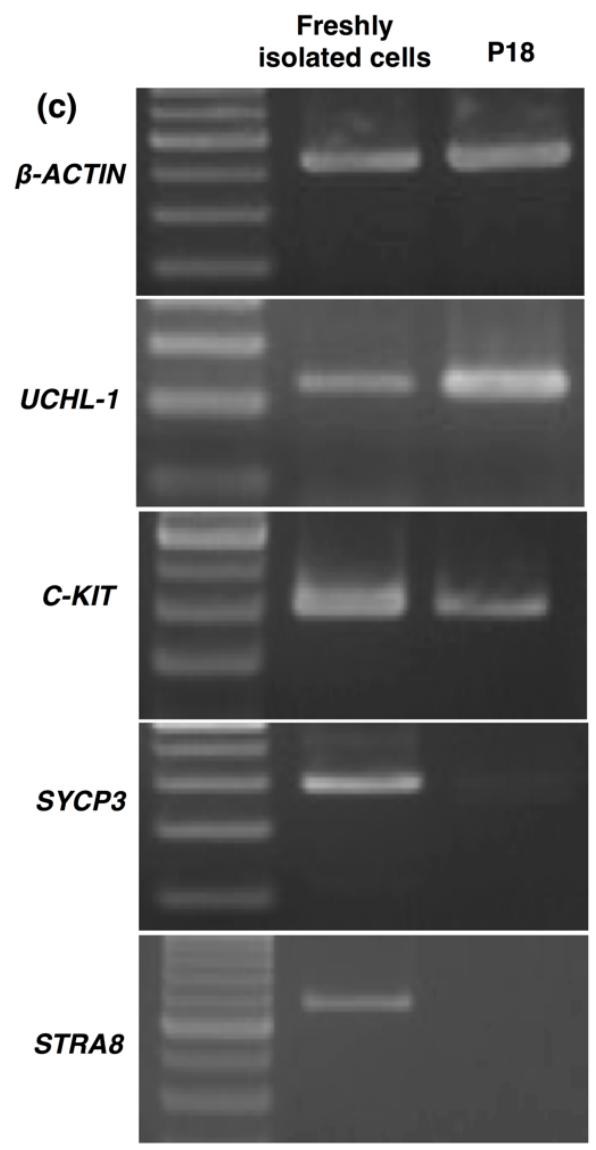

723

724 Figure S5. Morphology and immunofluorescence analysis of undifferentiated

725 spermatogonia colonies maintained in GDNF only. Botryoidally aggregated cell morphology

726 of colonies in the presence of GDNF (a), immunofluorescences analysis of UCHL-1, Sertoli

727 cell marker GATA4, and DBA (b), RT-PCR analysis of UCHL-1, C-KIT, STRA8, and SYCP3

728 at passage 18 (P18) (c). 